\title{
Results from an industrial size biogas-fed SOFC plant (the DEMOSOFC project)
}

\author{
Marta Gandiglio ${ }^{a, *}$, Andrea Lanzini ${ }^{a}$, Massimo Santarelli ${ }^{a}$, Marco Acri $^{b}$, \\ Tuomas Hakala $^{c}$, Markus Rautanen ${ }^{d}$ \\ a Politecnico di Torino, Department of Energy, Corso Duca degli Abruzzi 24, 10129, Torino, Italy \\ b SMAT - Società Metropolitana Acque Torino S.p.A., Corso XI Febbraio, 14, 10152, Torino, Italy \\ c Convion Ltd., Tekniikantie 12, FIN-02150 Espoo, Finland \\ ${ }^{\mathrm{d}}$ VTT Technical Research Centre of Finland Ltd., P.O. Box 1000, FI-02044 VTT, Finland
}

\section{H I G H L I G H T S}

- The first industrial size biogas-fed SOFC plant in Europe is presented in the work.

- The first installed SOFC module has reached more than $5600 \mathrm{~h}$ of operation.

- Measured SOFC efficiency from biogas to AC power is higher than $50-52 \%$ during operation.

- $\mathrm{NO}_{\mathrm{x}}, \mathrm{SO}_{2}, \mathrm{HCl}, \mathrm{HF}$, and organic compounds are all below detection limits in exhaust gas.

\section{A R T I C L E I N F O}

Article history:

Received 15 March 2019

Received in revised form

29 July 2019

Accepted 2 August 2019

Available online $\mathrm{xxx}$

\section{G R A P H I C A L A B S T R A C T}

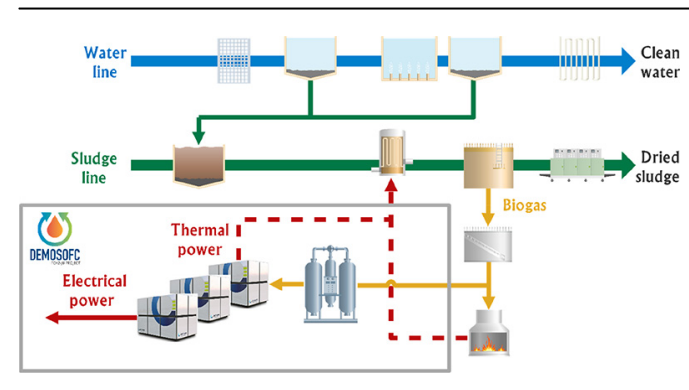

\begin{abstract}
A B S T R A C T
The EU-funded DEMOSOFC project aims to demonstrate the technical and economic feasibility of operating a $174 \mathrm{~kW}_{\mathrm{e}}$ Solid Oxide Fuel Cell (SOFC) in a wastewater treatment plant. The fuel for the three SOFC modules $\left(3 \times 58 \mathrm{~kW}_{\mathrm{e}}\right)$ is biogas, which is available on-site from the anaerobic digestion of sludge collected from treated wastewater. The integrated biogas-SOFC plant includes three main units: 1) the biogas cleaning and compression section, 2) the three SOFC power modules, and 3) the heat recovery loop. Main advantages of the proposed layout are the net electric efficiency of the SOFC, which is in the range 50 $-55 \%$, and the near-zero emissions. A specific focus of the demonstration project is the deep and reliable removal of harmful biogas contaminants. The presented work is related to the design of the SOFC system integrated into the wastewater treatment plant, followed by the analysis of the first results from the plant operation. We analyzed the biogas yearly profile to determine the optimal SOFC capacity to install that is 3 SOFC modules. The rational is to maintain high the capacity factor while minimizing the number of shutdown per year (due to biogas unavailability). First results from plant operation are also presented. The first SOFC module was activated in October 2017 and the second in October 2018. The
\end{abstract}

\footnotetext{
* Corresponding author.

E-mail addresses: marta.gandiglio@polito.it, marta.gandiglio@gmail.com (M. Gandiglio).
} https://doi.org/10.1016/j.ijhydene.2019.08.022

0360-3199/@ 2019 The Authors. Published by Elsevier Ltd on behalf of Hydrogen Energy Publications LLC. This is an open access article under the CC BY-NC-ND license (http://creativecommons.org/licenses/by-nc-nd/4.0/). 
measured SOFC efficiency from compressed biogas to AC power has always been higher than $50-52 \%$, with peaks of $56 \%$. Dedicated emissions measurements have been performed onsite during December 2017. Results on real biogas operation show $\mathrm{NO}_{\mathrm{x}}<20 \mathrm{mg} / \mathrm{m}^{3}$, $\mathrm{SO}_{2}<8 \mathrm{mg} / \mathrm{m}^{3}$ (detection limits for the instrument) and PM lower than ambient air values. (C) 2019 The Authors. Published by Elsevier Ltd on behalf of Hydrogen Energy Publications LLC. This is an open access article under the CC BY-NC-ND license (http:// creativecommons.org/licenses/by-nc-nd/4.0/).

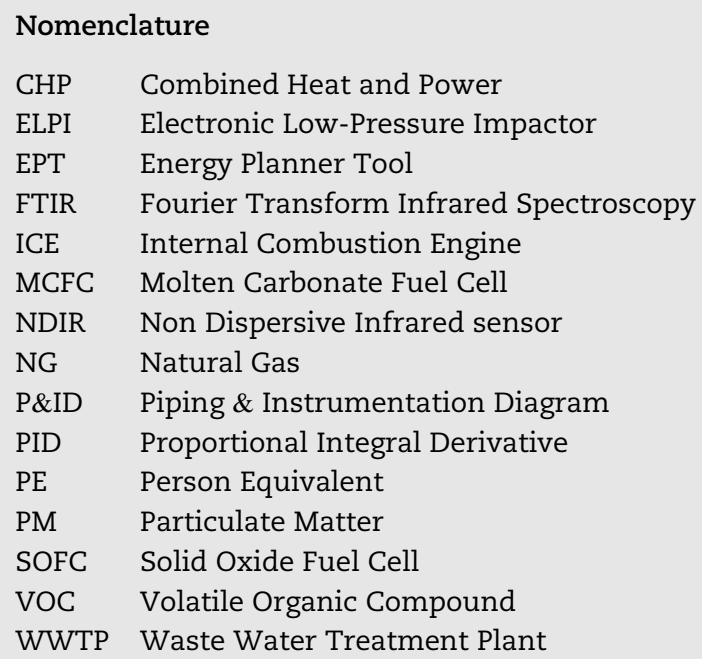

\section{Introduction}

The work presents the sizing methodology and the description of the DEMOSOFC plant, the first European industrial-size SOFC plant, fed by sewage biogas. The synergy between Waste Water Treatment Sector (WWTP) and Solid Oxide Fuel Cells (SOFC) is due to the small size of many WWTPs around Europe coupled with the unavailability of high-efficiency CHP systems for small power production plants.

The mean entering load among all the WWTPs in Europe is $26,889 \mathrm{PE}[1,2]$ : this value, also confirmed by single countries, shows how the plants' size distribution is composed of a massive number of small-medium size sites. If a minimum plant size for biogas production is considered (internal energy generation is crucial for the goal of self-sufficiency), only 5,141 plants (19.1\%) are large enough to include anaerobic digestion (with a minimum limit of $20^{\prime} 000$ P.E.) [3]. The EU WWTP average size correspond, considering a biogas production rate of 151 biogas/P.E./day, corresponds to a CHP size of $75 \mathrm{~kW}_{\mathrm{e}}$ (with an electrical efficiency of $53 \%[4])$.

Internal combustion engines (ICEs) shows efficiencies - in the range $10-100 \mathrm{~kW}_{\mathrm{e}}$ - between $28 \%$ and $37 \%$, and between 37 and $43 \%$ in the $100-1000 \mathrm{~kW}_{\mathrm{e}}$ range [5]. Because of the non-modularity of ICEs, not only efficiencies are lower at small size but also costs are increased, and in the $10-100 \mathrm{~kW}_{\mathrm{e}}$ range, specific investment costs are varying between $3^{\prime} 000$
$€ / \mathrm{kW}$ and $1^{\prime} 000 € / \mathrm{kW}$. Because of these reduced performance and higher costs at low sizes for ICEs, small and medium size biogas plants are facing the need for highefficiency CHP systems like high temperature fuel cells. Furthermore, because of environmental limitations on $\mathrm{NO}_{\mathrm{x}}$, $\mathrm{SO}_{\mathrm{x}}$ and Particulate Matter (PM), ICEs are usually installed with a downstream post combustor able to reduce pollutants emissions to the environment and respect the normative values; this extra BoP generates a further cost increase. Fuel cell systems, on the other side, can generate electrical and thermal power with near-zero emissions to the atmosphere $[6,7]$.

In the view of future energy self-sufficient WWTPs, the use of high-efficiency onsite energy generators is also a key factor. The operation of WWTP sites requires a large amount of electricity, and the goal of energy self-sufficiency could be reached only by combining optimization/improvement processes in different plant sections. The key segments in which plant owners' efforts should be directed are the secondary biological treatment, where aeration is performed, and the water pumps. Energy consumption reduction should also be coupled with an increase of internal energy production, usually related to biogas from sewage sludge. Sludge pretreatments and anaerobic digestion management are key drivers to increase biogas yield and reduce the energy consumption of the sludge line. Furthermore, the use of codigestion with other organic wastes is another potential way to increase onsite energy generation. Biogas can be then efficiently converted into electricity (and heat) via high temperature fuel cell generators [1].

The DEMOSOFC plant [8] is the first European industrialsize Solid Oxide Fuel Cell (SOFC) system. The plant aims at demonstrating the technical and economic feasibility of industrial-size SOFC systems, with focus on bio-based fuels feedings (e.g., biogas). Industrial-size fuel cell systems, usually Molten Carbonate Fuel Cells (MCFCs) are already available outside Europe, especially in USA $[9,10]$, Japan and South Korea [7], but not yet in EU. Key advantages of fuel cell based industrial systems in biogas plants have been deeply demonstration in the authors' previous works [1,6,11-13] and include:

- High efficiency increase respect to traditional biogas-fed Internal Combustion Engines (ICEs), especially for lowmedium size systems.

- Zero emissions to the atmosphere in terms of $\mathrm{NO}_{\mathrm{x}}, \mathrm{SO}_{\mathrm{x}}$, VOC, and PM, which are traditionally a criticality in internal combustion engines. 
The scientific and research activity in the framework of the DEMOSOFC project has been related - in this first years - to the biogas purification system (required to be more efficiency and robust than the one for traditional ICEs [14]) and the overall system management (in terms of control algorithms and interface with the real WWTP).

In the work from Saadabadi et al. [15] - published in 2015 a complete review on the SoA of biogas-fed fuel cell system is provided. The authors discussed the technical challenges and opportunities of the biogas and fuel cell coupling, from the cleaning section (to remove harmful contaminants) to the methane reforming section. Furthermore, existing DEMO projects in the field are listed, among which the Biocell project [16] in Barcelona, where both a PEMFC and an SOFC system were tested under biogas feeding, and the SOFCOM project [17] - coordinated by the authors of this work where a $2 \mathrm{~kW}_{\mathrm{e}}$ SOFC system run for more than $600 \mathrm{~h}$ with sewage biogas.

The main novelty of the proposed work is related to the DEMOSOFC plant itself that, being the first-of-its-kind system in EU, has generated a strong interest for what concerns both its design and its operation. The biogas treatment unit is also an innovative system able to reach near-zero contaminants level in the outlet biogas sent to the fuel cells. SOFC producer limits on inlet contaminants (10 ppb siloxanes and $30 \mathrm{ppb}$ sulfur) required a new design of the traditional cleaning systems used for ICE-based plants. The SOFC modules - being a pre-commercial product - are considered as a black box in the project. The objective is the analysis of their performance in the long term (which will be available at the end of the project) and their integration within the WWTP taking into account fuel availability and loads (as will be shown in the sizing methodology section). Finally, the electrical system layout is developed with a non-conventional design, since the SOFC modules can work in island mode and guarantee power production even during grid failures, thus acting as an innovative back-up power unit.

The DEMOSOFC site WWTP is located in Collegno, in the Torino premises (IT). The Collegno plant has a nominal capacity of $250^{\prime} 000$ Person Equivalent (P.E.), and it is currently serving around 180'000 P.E., both residential and industrial. The plant used to exploit biogas for heating-only purpose in a boiler, for pre-heating the sludge entering the anaerobic digester, and excess biogas - not sent to boilers - was simply flared. The new integrated biogas-SOFC plant, installed in the framework of the DEMOSOFC project, is using the asproduced biogas for electrical and thermal energy production in an SOFC-based cogeneration system.

The present work includes a first section where the plant sizing methodology is described. A rigorous Energy Planner Tool has been developed at the beginning of the project (2015-2016) to define the optimal number of SOFC modules for the selected plant. The tool has also been used as a real PID for the control system within the plant since it can optimize the plant operation and reducing the number of plant shutdown. The second part is related to the technical description of the plant, focusing on the cleaning system design, the SOFC modules boundaries, the heat recovery unit and the electrical and control connections. Finally, the first results related to the early hours of operation are shown.

\section{Sizing methodology of the DEMOSOFC plant}

The choice of 3 SOFC modules $\left(3 \times 58 \mathrm{~kW}_{\mathrm{e}}, 174 \mathrm{~kW}\right.$ nominal power) was derived from a rigorous sizing process reached through the development of an Energy Planner Tool (EPT) for the DEMOSOFC plant [18]. The tool can simulate - based on real historical data - the operation of the plant in an optimal way (through an in-house formulated PID controller) and was used to find the optimal number of SOFC modules to be installed within the WWTP.

Fig. 1 shows the hourly biogas production in the SMAT Collegno WWTP for years 2014 and 2015 and the nominal biogas flow rate feeding the 3 SOFCs according to the producer nominal datasheet [4]: these are the hourly input data of the EPT and have been used for the sizing procedure.

In Fig. 1 the high fluctuation of biogas production during the year is observed. During Summer months, the biogas coming from the digester is always lower than the SOFC nominal consumption. Reduced biogas production during summer months is due to the decreasing inlet wastewater treated by the plant because of the holiday season. When sizing and planning the operation of the SOFC system, fluctuations on the biogas availability along the day and the year need to be considered. This determines the need for a dedicated protocol of control, able to first preserve the SOFC modules, and then optimise the energy recovery from the plant. The goal was reached through the development of the energy planner tool.

\section{Energy planner tool}

The sludge anaerobic digestion process produces biogas that is stored in the gas holder. The digester operates continuously during the year. However, seasonal variations of the amount of sludge treated and daily variations of the temperature inside the digester tank make the hourly biogas production rate quite fluctuating (see Fig. 1).

The control system regulates the net electrical power produced by the SOFC by measuring the level of biogas stored in the gas holder. The error between this value and a fixed set point value defined by the user is provided as input data for a PID (Proportional-Integrated-Derivative) controller that generates the control signal to the SOFC. Using the powerefficiency curve of the SOFC - provided by the manufacturer - the hourly biogas flow rate consumed by the fuel cell, and the thermal power generated, are then calculated. The biogas that exceeds the gas holder maximum capacity is used partially to feed an existing biogas boiler (to cover the digester thermal demand partially) and partially sent to the flare, when in excess. A graphical description of the control system is shown in Fig. 2.

The quantity of thermal and electrical power produced by the SOFC and the amount of biogas sent to the boiler are used to calculate the natural gas required to fully cover the digester thermal load (when thermal production from biogas is not enough) and the electricity bought from the grid to fully cover the electrical consumption of the plant. Electrical and thermal demand of the plant are respectively retrieved from SMAT energy management section and calculated starting from the 
- Data 2015 - Data 2014 -SOFC Nominal biogas consumption

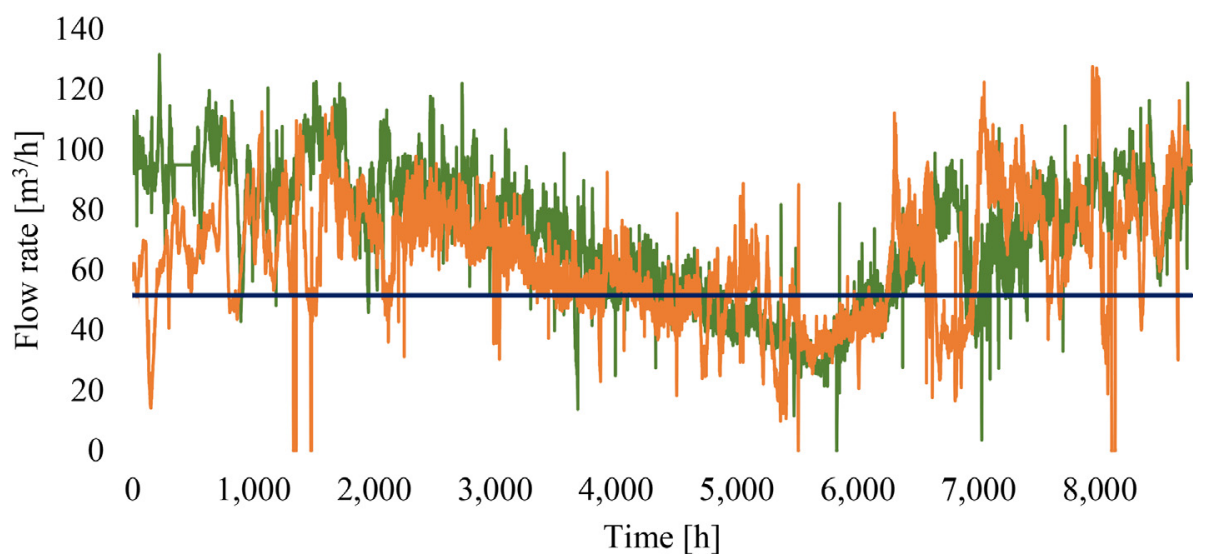

Fig. 1 - Biogas flow rate in 2014, 2015 and SOFC nominal biogas consumption in the DEMOSOFC project.

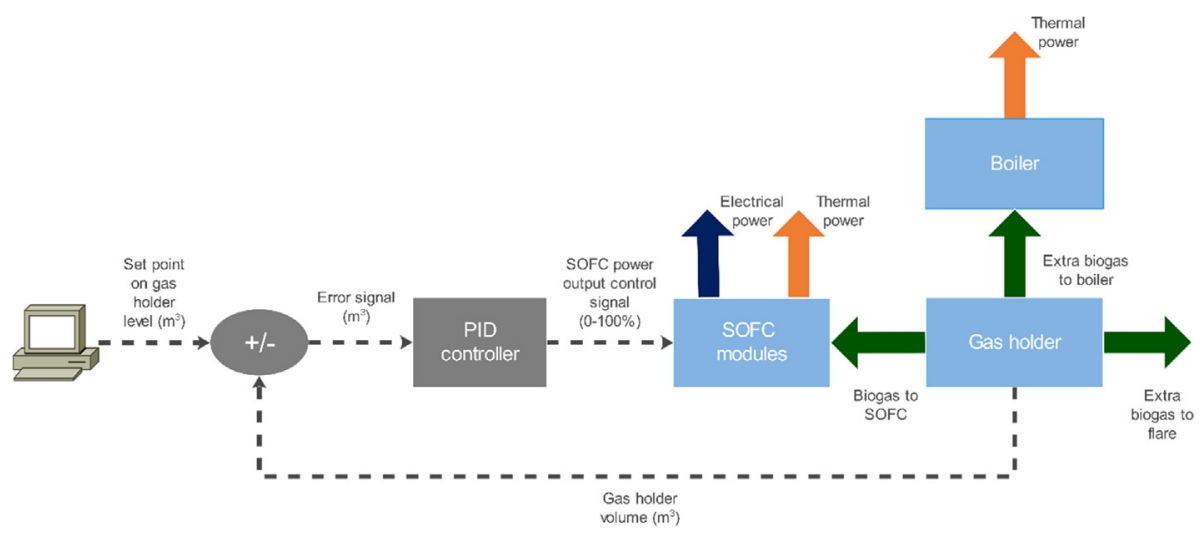

Fig. 2 - Regulation strategy of the biogas-fed SOFC system.

inlet sludge flow and the digester temperature (as explained in authors' previous works [19-21]).

\section{PID controller}

The control algorithm of the DEMOSOFC plant is based on a PID regulator that can automatically control the SOFC electrical power output based on the amount of biogas available in the gas holder, trying to avoid the risk of a fuel shortage while, at the same time, maximizing SOFC electrical and thermal production.

The PID regulator is driven mainly by the output signal generated by the radar sensor located in the gas holder and compares the read value with a fixed setpoint defined by the user. The difference produced by the comparison is used as a control parameter to regulate the electrical power generated by the SOFC (user set point, 0-100\%).

A set of modulation ranges of the SOFC are defined to calculate the hourly biogas flow rate feeding the SOFC, according to the amount of biogas available in the gas holder (Fig. 3):

- The PID controller regulates the SOFC between full load $(100 \%)$ and half load (50\%) if the volume of biogas stored in the gas holder is between the maximum and an intermediate level (blue bar in Fig. 3). When the amount of biogas stored exceeds the upper limit of the gas holder, this can be sent or to the boiler or the flare depending on the thermal demand required by the digester.

- If instead, the volume of biogas stored moves down the lower limit (minimum level), the extraction is interrupted, and consequently, the shutdown procedure of the SOFC modules starts (orange bar in Fig. 3).

- When the volume of biogas stored in the gas holder is between the intermediate and the minimum level, the PID controller is off, and the fuel cell is forced to operate at $30 \%$ of its nominal power (green bar in Fig. 3). In this condition the biogas consumed by the SOFC is lower, according to the electrical efficiency curve, allowing the re-filling of the gas holder. However, the SOFC cannot stay in this condition for an extended period. Hence, after an imposed hour period (set as $48 \mathrm{~h}$ but can be varied), the SOFC will be shut down if the volume of the gas holder is still between the minimum level and the intermediate level.

The intermediate level used in the algorithm is optimized (by a simulation procedure) with the target of saving biogas and especially of minimizing the shutdowns (thermal cycles) of the SOFC modules, as during start-ups and shutdowns the 


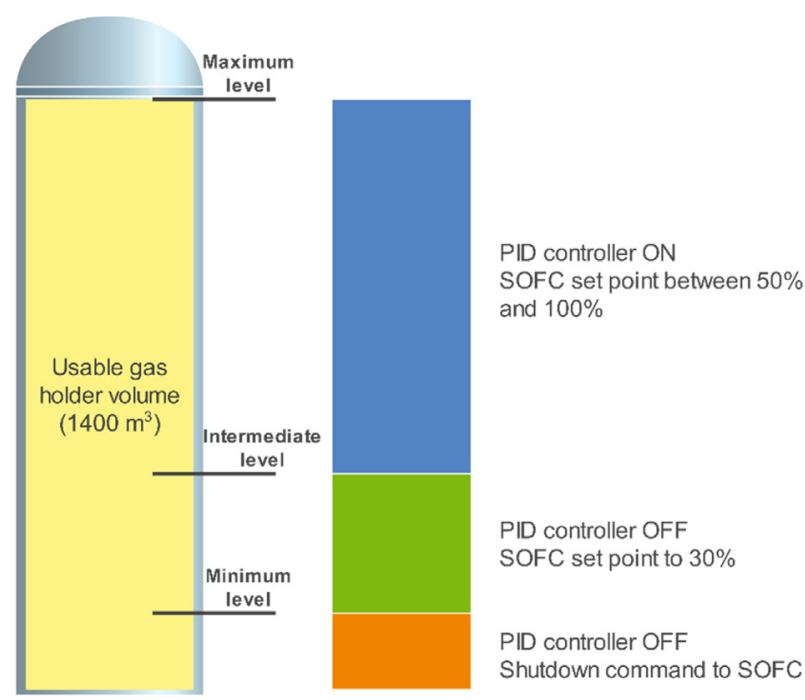

Fig. 3 - SOFC modulation range according to biogas availability in the gas holder tank.

fuel cell units are subjected to thermal stresses that may lead to fatigue and permanent damage [22].

The output values of the EPT are:

- Electricity and thermal power recovered during a reference year of operation;

- Natural gas and electricity that has to be bought from the grid to cover the thermal and electrical load of the plant;

- Number of forced shut-downs of the modules due to a low volume of biogas in the gas holder (below minimum level):

- Equivalent capacity factor at full load, equal to the number of hours in which all modules run at $100 \%$ load respect to the overall number of hours in a year.

Input data for the model are summarized - for the baseline case analysis - in Table 1. A view of the EPT is also shown in Fig. 4.

\section{Table 1 - Input data for the Energy Planner Tool.}

\begin{tabular}{lll} 
Gas holder PID parameters & Value & \multicolumn{1}{c}{ Unit } \\
\hline Gas holder maximum level & 1400 & $\mathrm{~m}^{3}$ \\
Intermediate level & 400 & $\mathrm{~m}^{3}$ \\
Gas holder minimum level & 300 & $\mathrm{~m}^{3}$ \\
Minimum Gas Holder Level for restart & 600 & $\mathrm{~m}^{3}$ \\
Average Biogas chemical composition & & \\
Methane $-\mathrm{CH}_{4}$ & 64 & $\%$ \\
Carbon dioxide $-\mathrm{CO}_{2}$ & 36 & $\%$ \\
SOFC Parameters & & \\
Net power output AC & 58.3 & $\mathrm{~kW}$ \\
Ramp limits & 13.3 & $\mathrm{~kW}_{\mathrm{e}} / \mathrm{h} /$ module \\
Max Period at 30\% of nominal power & 48 & $\mathrm{~h}$ \\
Start-up period & 24 & $\mathrm{~h}$ \\
Shut-down period & 24 & $\mathrm{~h}$ \\
Shut-down/Start-up procedure & & \\
Electrical power absorbed & 7.6 & $\mathrm{~kW}$ \\
Biogas consumed & 2.82 & $\mathrm{Nm} / \mathrm{h}$ \\
Energy efficiency (LHV) & & \\
Electrical (net AC) & $>53$ & $\%$ \\
Total (Exhaust 60 ${ }^{\circ} \mathrm{C}$ ) & $>80$ & $\%$ \\
\hline
\end{tabular}

The EPT also estimates the costs of extra energy (electricity and natural gas) which need to be bought from the grid to cover electrical and thermal loads fully. The economic evaluation of the plant is not included in the presented work since it was not used for the DEMOSOFC system sizing.

\section{EPT results}

The simulation of the control system has been developed for different scenarios to evaluate the best plant layout and size it to both maximize the capacity factor and the biogas use in the fuel cell. The analysis has been performed with a variable number of SOFC modules $(1,2,3,4)$, considering the biogas flow rate data from 2014 to 2015. Results are shown in Table 2 and Fig. 5.

In the solution with one and two the number of shutdowns events is zero, which means that the volume of the gas holder always stays over the minimum value of $300 \mathrm{~m}^{3}$, but biogas consumption in the fuel cell is only 27 and $54 \%$ respectively, because of the reduced system size. The optimal system size is, as can be seen from Fig. 5, between 3 and 4 SOFC modules; with three modules capacity factor is higher and the number of shutdown lower, while with four modules there is a higher use of biogas in the fuel cell system. The choice of installing three modules was also an optimal decision because the number of shutdown events is limited to 1 in 2 years (once in 2014 and zero in 2015 because biogas production was higher). The simulations show that there would be room for an additional module, which would result in almost full biogas utilization and electrical valorization in SOFC modules. However, the equivalent capacity factor reduces $8 \%$ percentage points and more frequents shut-down of the SOFC are necessary (3 per year).

With the chosen 3 SOFC module size, the profile of gas holder volume and fuel cell electrical output (zoom on a high variability period) are shown in Fig. 6 and Fig. 7.

\section{DEMOSOFC plant layout}

The DEMOSOFC plant - sized according to Chapter 3 methodology - includes three main sections: 1) the biogas cleaning and compression section, 2) the SOFC power modules, and 3) the heat recovery loop. Fig. 8 shows a schematic layout of the WWTP process and its integration with the DEMOSOFC plant.

\section{Biogas cleaning section}

The biogas cleaning system includes two sub-sections (Fig. 9). The first part is located close to the digester where biogas is produced (anaerobic digester) and stored (gas holder, around one day of storage capacity).

Biogas is found in the gas holder at a pressure slightly over the ambient one (15-20 mbar overpressure). In the first section, biogas is pressurized (from near-atmospheric pressure to 400 mbar(g)) to reach the DEMOSOFC area, located around 100-150 $\mathrm{m}$ from the biogas production area. After the blower, a first chiller (working with an $8-10{ }^{\circ} \mathrm{C}$ dew point) is also installed to remove water from the biogas line and avoid condensation in the pipeline. The biogas is then sent to the 


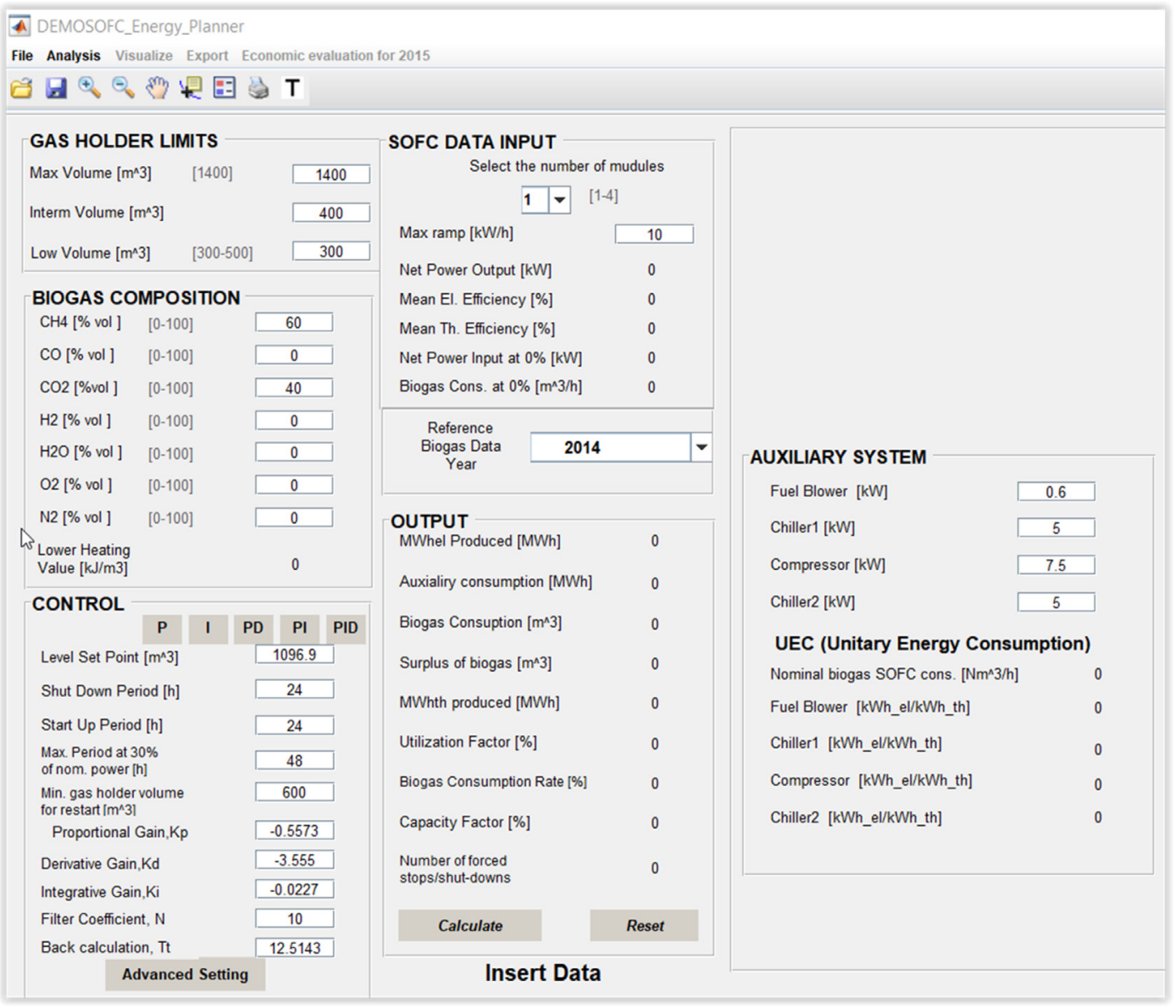

Fig. 4 - Energy Planner Tool (Matlab ${ }^{\circledR}$ based) layout.

DEMOSOFC area through an insulated pipeline (aboveground). In the DEMOSOFC area, all pipes are indeed underground.

The second section is located inside a container and includes adsorption vessels for biogas contaminants removal and a compressor (since biogas is required at 4 bar $(\mathrm{g})$ at the SOFC inlet). Commercial impregnated activated carbons, selective for sulfur and siloxanes compounds removal, are chosen as media for the biogas cleaning. The selection of the sorbents has been done after a 1-year experimental lab activity in Politecnico di Torino, where different sorbents were tested in different boundary conditions (level of contaminants, the presence of oxygen, etc.), and four laboratory analysis on the Collegno WWTP biogas. The sorbents able to both maximize the

Table 2 - Results of the energy planner tool for 1,2,3,4 SOFC installed modules.

\begin{tabular}{lllll} 
& \multicolumn{4}{l}{$2014+2015$} \\
\hline Number of SOFC Modules & 1 & 2 & 3 & 4 \\
Electrical energy [MWh/y] & 1008 & 2001 & 2837 & 3377 \\
Auxiliary consumption [MWh/y] & 313 & 310 & 310 & 263 \\
Thermal energy [MWh/y] & 502 & 993 & 1380 & 1603 \\
Number of shut-down & 0 & 0 & 1 & 6 \\
Biogas consumption [\%] & 27 & 54 & 77 & 92 \\
Capacity Factor [\%] & 100 & 99 & 94 & 86 \\
\hline
\end{tabular}

performance (with the SMAT Collegno biogas composition) and minimize the costs were chosen [23-25].

For the $\mathrm{H}_{2} \mathrm{~S}$ and siloxanes removal, different commercial activated carbons were tested from different producers. The analysis which mostly affected the choice of the final sorbents are represented in Fig. 10. For $\mathrm{H}_{2} \mathrm{~S}$ removal (left side of Fig. 10), three activated carbons have been selected from this screening tests on the influence of oxygen. As can be seen, the two sorbents with low performance on biogas without oxygen (CKC and CKI) showed a massive improvement in their adsorption capacity even with a very low percentage of oxygen $\left(0.1 \% \mathrm{O}_{2}\right)$. On the other side, the high-performance material (R8G) was not affected by the oxygen content. These tests were performed with a matrix of $\mathrm{CH}_{4}-\mathrm{CO}_{2}(62.5-37.5 \%)$ with $95 \mathrm{ppm} \mathrm{H}_{2} \mathrm{~S}$, a total flow rate of $200 \mathrm{ml} / \mathrm{min}$ (gas velocity $0.265 \mathrm{~m} / \mathrm{s}$ ) and a sample of $4 \mathrm{~mm}$ diameter (with sorbents in powder form).

The selected sorbents (CKC and C64) properties are shown in Table 3.

Different tests were performed on the influence of oxygen and results pointed out that its presence always improves the performances of activated carbons, but it seems that the entity of this positive effect is subjected to the features of each single material [26]. This consideration is well demonstrated also in literature where other kinds of activated carbons have been tested showing positive variations of adsorption 


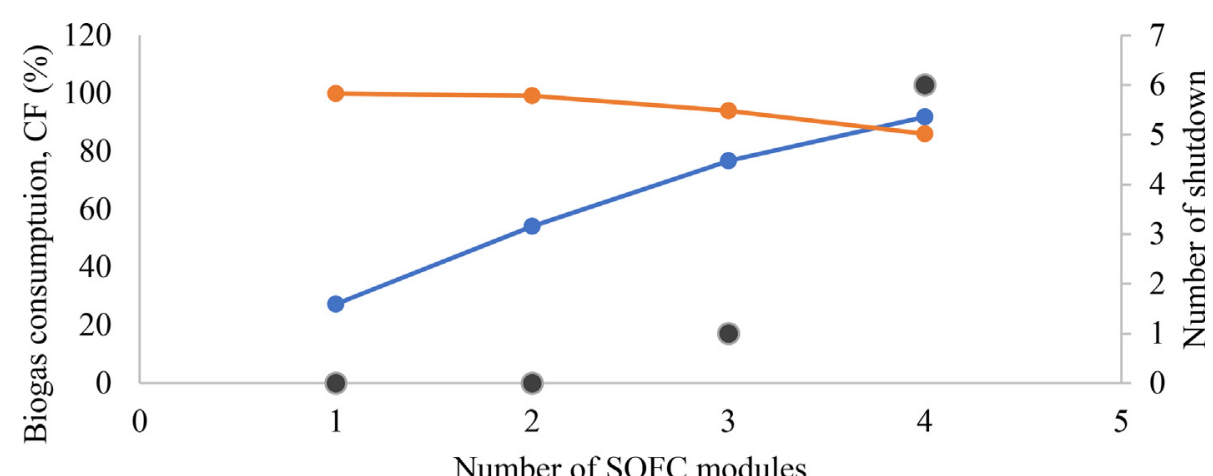

Number of SOFC modules

$\rightarrow-$ Biogas consumption [\%] $\rightarrow$ Capacity Factor [\%] $\quad$ Number of shut-down

Fig. 5 - Biogas consumption rate, capacity factor and number of shutdown for the four analyzed configurations.

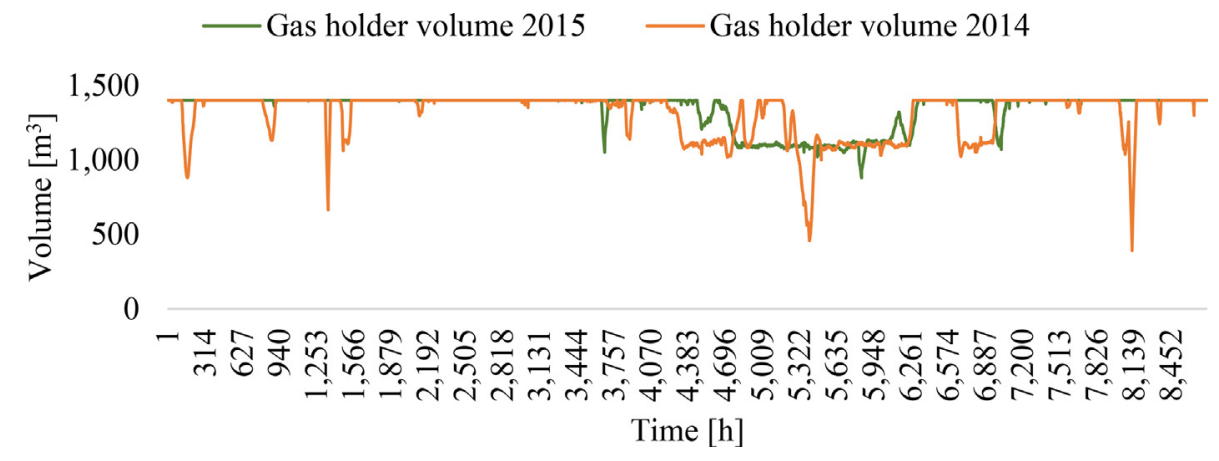

Fig. 6 - Gas holder volume during years 2014 and 2015.

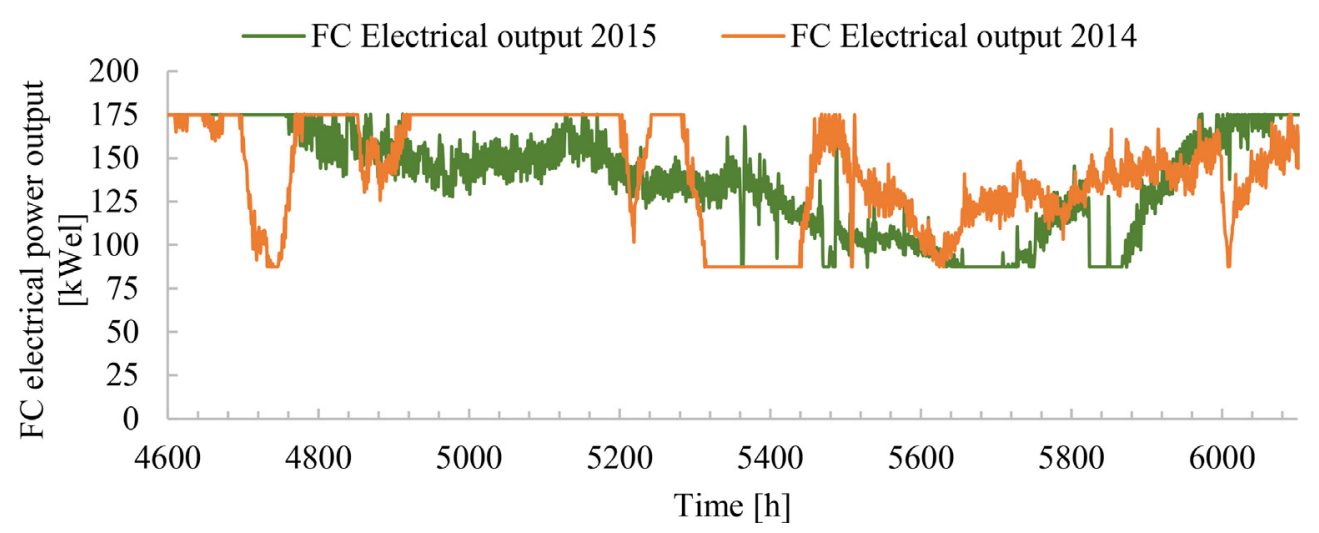

Fig. 7 - SOFC modules power modulation during a period of highly fluctuating biogas production.

capacities ranging from around $100 \%-700 \%$ [27-29]. The choice of using CKC sorbent was due to the highest performance in presence of oxygen. The availability of oxygen - in small quantities - inside the biogas was confirmed by the 2015-2016 external laboratory analysis on the Collegno WWTP biogas (Fig. 11) which always detected $\mathrm{O}_{2}$ in the range $0.01-0.33 \%$.

For siloxanes removal (right side of Fig. 10) the sorbent selected was C64, because of its highest performance during the test session. Siloxanes testing were performed with powder sorbents in small reactors at speed $0.27 \mathrm{~m} / \mathrm{s}$ and 20 ppm D4 concentration in biogas.
The final cleaning system P\&ID is shown in Fig. 9. A leadand-lag layout is used for the first four vessels connection: the four reactors can work in series during nominal operation (with the first two lead reactors followed by the second two lag reactors). When contaminants breakthrough is detected after the lead reactors, the system is switched - thanks to a series of valves - into the parallel mode to avoid the stop of the SOFC units during the maintenance. While the lag reactors are kept working, the lead ones are replaced. Lead and lag are then switched to guarantee the cleanest reactor to be always the last one in the sequence. A second scavenger section (made of two reactors) is also available as guard bed. 


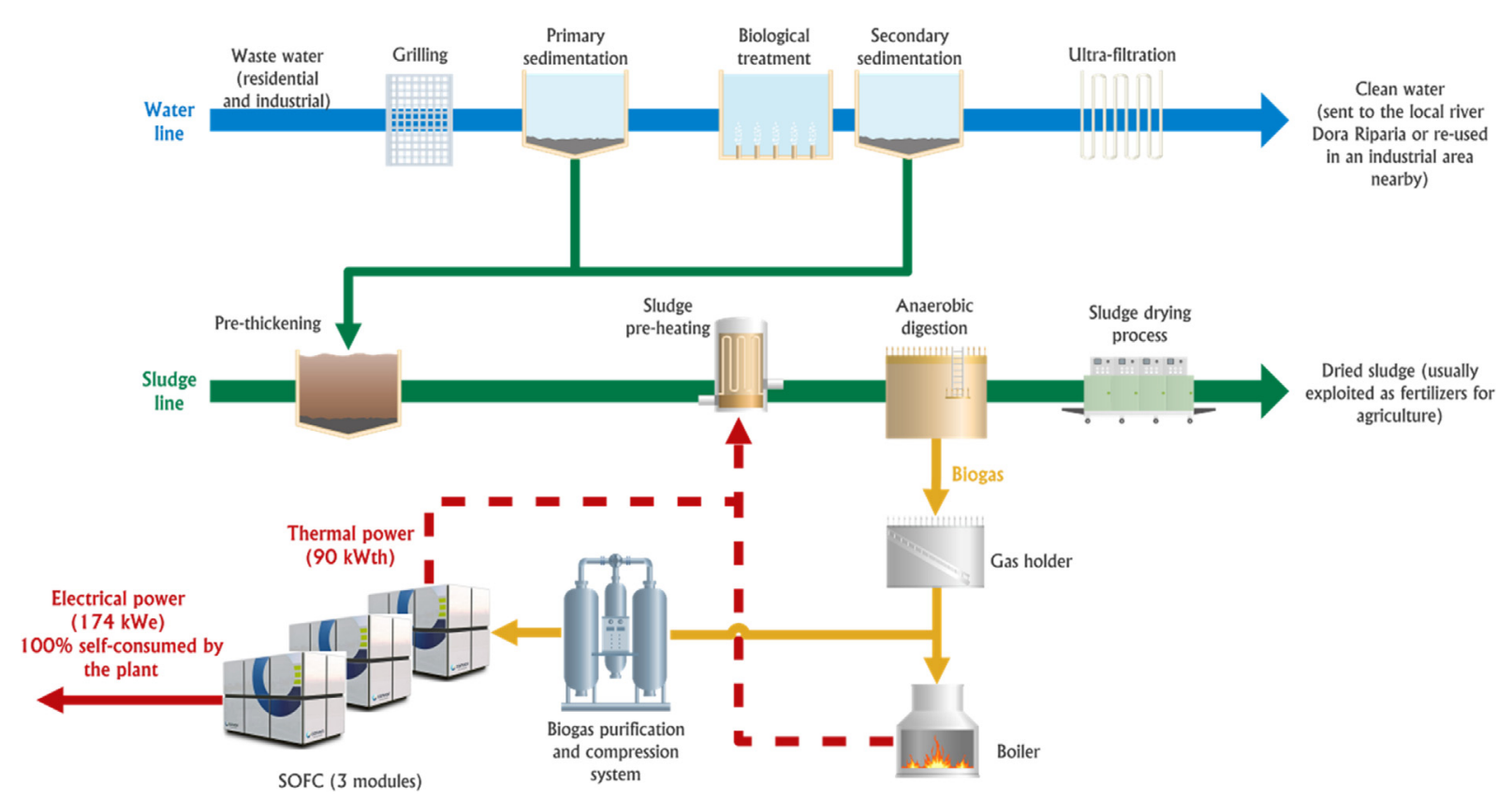

Fig. 8 - DEMOSOFC plant layout.

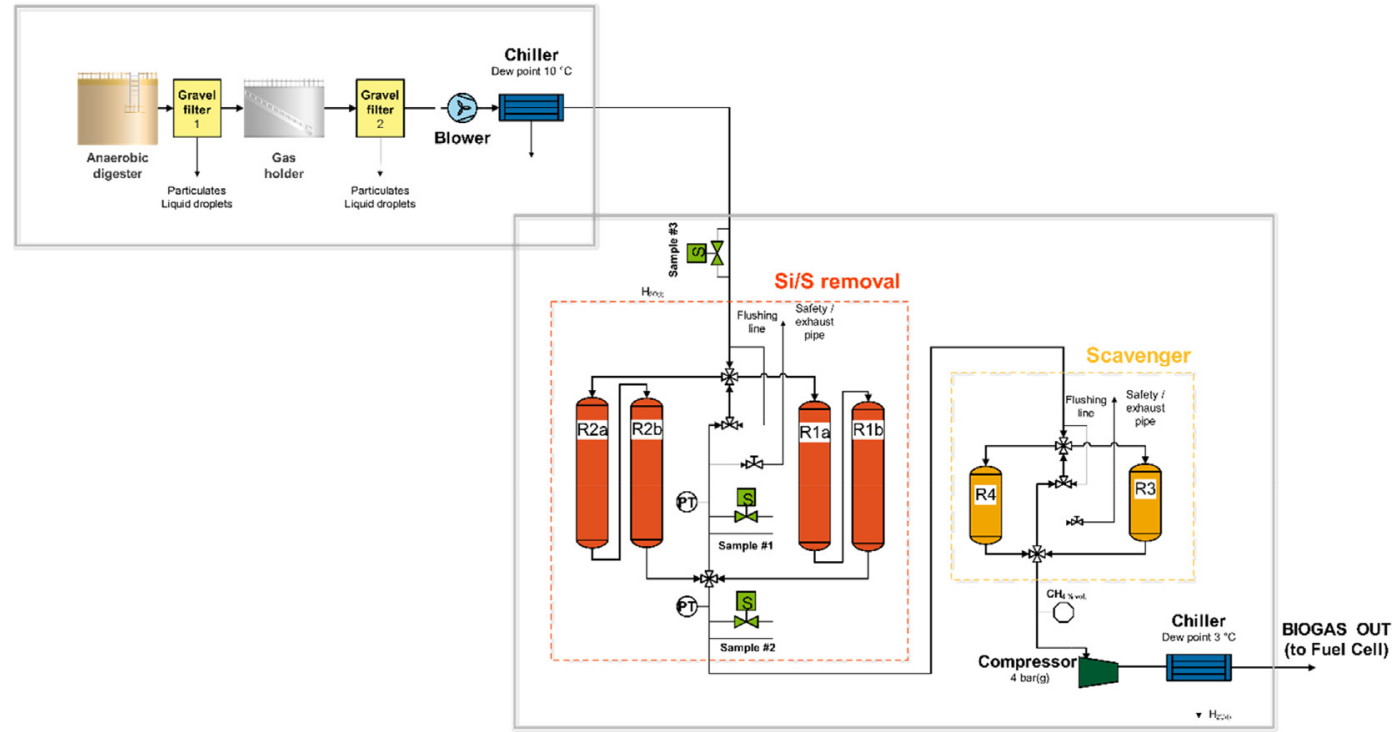

Fig. 9 - Biogas cleaning and compression section layout.
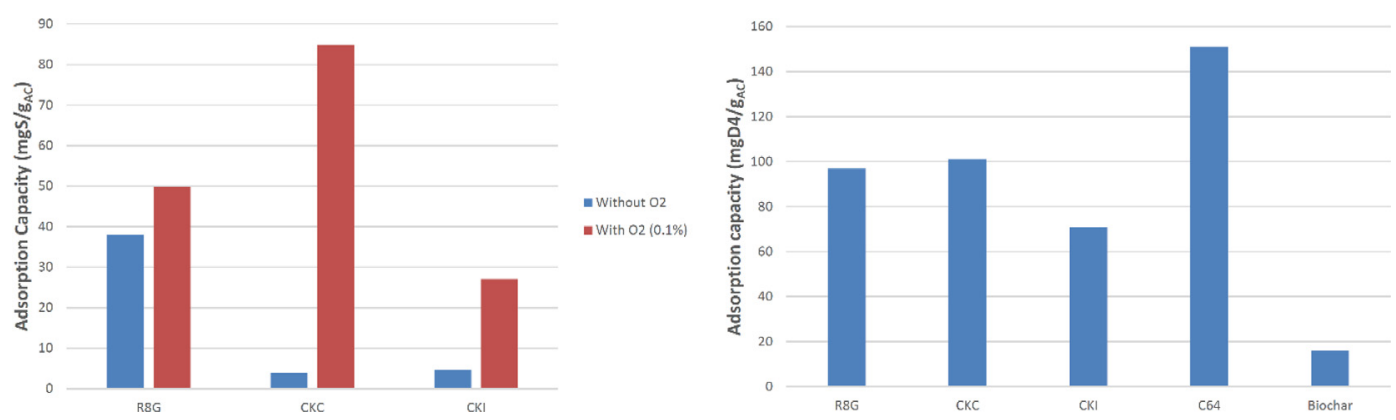

Fig. 10 - On the left: influence of oxygen on $\mathrm{H}_{2} \mathrm{~S}$ adsorption capacity of three commercial activated carbons. On the right: screening test of four commercial activated carbons and one bio-based sorbent [26]. 
Table 3 - DEMOSOFC sorbents properties (from the provider datasheet).

Sorbent

CKC C64

\section{Pellet diameter}

Iodine content (ASTM 4607)

Moisture content at filling

(ASTM D2867)

Ashes (ASTM D2866)

Apparent density (ASTM D2854)

Specific surface BET (BET method)

Adsorption of $\mathrm{CCl}_{4}$ (ASTM D3467)

pH (ASTM 3838)

$\mathrm{H}_{2} \mathrm{~S}$ loading rate (ASTM D6646)

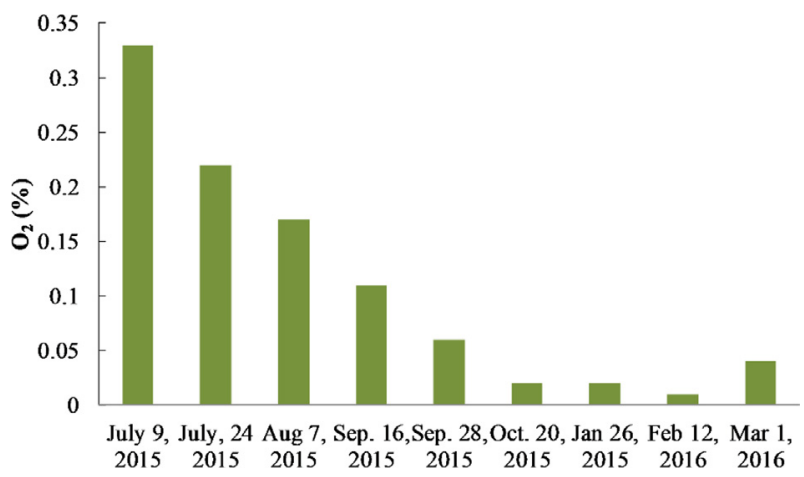

Fig. 11 - Oxygen content in Collegno WWTP biogas.

A continuous gas analyzer able to detect $\mathrm{CH}_{4}, \mathrm{CO}_{2}, \mathrm{O}_{2}, \mathrm{H}_{2} \mathrm{~S}$ and total Silicon (supplied by Qualvista Ltd [30]) is installed and measure the biogas composition with an overall sampling and measuring time of $40 \mathrm{~min}$ per sample. The system analyzes raw biogas once per day (\#S3 in Fig. 9; to avoid sending too many contaminants inside the analyzer) and clean gas (alternatively between and after the four vessels, samples \#S1 and \#S2 in Fig. 9) the rest of the day. Samples are designed so that \#S1 will always be the 'middle' sample and \#S2 the outlet sample, even after the lead-and-lag switch during the maintenance break.

The second part of the container is the screw compressor, which increase biogas pressure up to 4 bar(g), as requested at the SOFC module inlet. The biogas cleaning and compression section has been designed by Politecnico di Torino and Biokomp, and then manufactured and supplied by Biokomp [31].

The biogas cleaning system has been designed after oneyear monitoring of biogas composition in Collegno, where $\mathrm{H}_{2} \mathrm{~S}$ (average $20 \mathrm{ppm}$ ) and siloxanes (average $1 \mathrm{ppm}$ ) have been detected as the most harmful components to be removed. An in-line and real-time gas analysis (supplied by Qualvista LTD [30]) is installed to monitor the removal efficiency of the biogas clean-up unit. The online gas sensor can detect both macro-composition $\left(\mathrm{CH}_{4}, \mathrm{CO}_{2}, \mathrm{O}_{2}\right)$ and contaminants $\left(\mathrm{H}_{2} \mathrm{~S}\right.$ and total Silicon) continuously (Table 4).

\section{SOFC modules}

The core of the DEMOSOFC plant are the three SOFC units supplied by Convion, partner of the DEMOSOFC project. The modules can provide up to 55\% electrical efficiency and $30 \%$ thermal efficiency [4]. The three SOFC modules will produce $174 \mathrm{~kW}_{\mathrm{e}}$, which will cover around $25-30 \%$ of the WWTP electrical consumption [1].

Currently, 2 out of 3 SOFC modules are running at the DEMOSOFC site. The first module was started in October 2017 and the second one in October 2018. The SOFC units, as shown in Fig. 12, are fed by biogas during nominal operation and are connected to the heat recovery system (water-glycol loop). Compressed air is required during start-up, and an $\mathrm{N}-\mathrm{H}$ mixture $\left(95 \% \mathrm{~N}_{2}, 5 \% \mathrm{H}_{2}\right)$ is available for standby operation (maximum $24 \mathrm{~h}$ maintenance on the biogas line - e.g., compressor maintenance - with the SOFC system hot, thus avoiding shutdown).

Electrical and thermal efficiencies shown in the results section have been evaluated as follows:

$\eta_{e l}=\frac{\mathrm{W}_{e l, \mathrm{AC}, \mathrm{SOFC}}}{\dot{m}_{\text {biogas }} \cdot \% \mathrm{CH}_{4} \cdot \mathrm{LHV}_{\mathrm{CH}_{4}}}$

$\eta_{\text {th }}=\frac{\dot{m}_{\mathrm{H}_{2} \mathrm{O}+\text { glycol }} \cdot c_{p, \mathrm{H}_{2} \mathrm{O}+\text { glycol }} \cdot\left(\mathrm{T}_{w, \text { out }}-\mathrm{T}_{w, \text { in }}\right)}{\dot{m}_{\text {biogas }} \cdot \% \mathrm{CH}_{4} \cdot \mathrm{LHV}_{\mathrm{CH}_{4}}}$

Where:

- $\mathrm{W}_{\text {el,AC, SOFC }}$ is the AC power production from the SOFC module which already includes all the internal losses within the module and the DC/AC conversion. Details on the internal losses are out of the scope of the project, where the SOFC module is considered as a black-box unit.

- $\dot{m}_{\text {biogas }}$ is the biogas mass flow rate (on a mass basis) measured both in the biogas line (at the inlet of the DEMOSOFC area) and at the SOFC module entrance.

- \% $\mathrm{CH}_{4}$ is the mass percentage of methane included in the biogas, measured both by the Qualvista online gas analyzer and also by a sensor (the same measuring also the biogas flow rate) installed at the inlet of the biogas line.

- $\mathrm{LHV}_{\mathrm{CH}_{4}}$ is the Lower Heating Value of $\mathrm{CH}_{4}$, assumed as $50 \mathrm{MJ} / \mathrm{kg}$.

- $\dot{\mathrm{m}}_{\mathrm{H}_{2} \mathrm{O}+\text { glycol }}$ is the mass flow rate of the intermediate loop (see section Heat recovery section) of the heat recovery system, which receives the heat from the SOFC exhaust gases. The stream is composed of a mixture of water and glycol (to avoid freezing problems). The value is measured by a dedicate inline sensor.

\section{Table 4 - Qualvista analyser measuring principles detection limits [30].}

\begin{tabular}{|c|c|c|c|c|}
\hline & $\mathrm{H}_{2} \mathrm{~S}$ & $\mathrm{O}_{2}$ & $\mathrm{CO}_{2}, \mathrm{CH}_{4}$ & Siloxanes \\
\hline Measurement principle & Electrochemical & Electrochemical & NDIR & NDIR \\
\hline Measurement range & $0-500 \mathrm{ppm}$ & $0-22$ vol\% & $0-100$ vol\% & 0-100 mgSi $/ \mathrm{m}^{3}$ (D5 eq.) \\
\hline Detection limit & & & $\leq \pm 0,2$ & $0.1 \mathrm{mgSi} / \mathrm{m}^{3} @ 500 \mathrm{~s} @ 24{ }^{\circ} \mathrm{C}$ \\
\hline
\end{tabular}




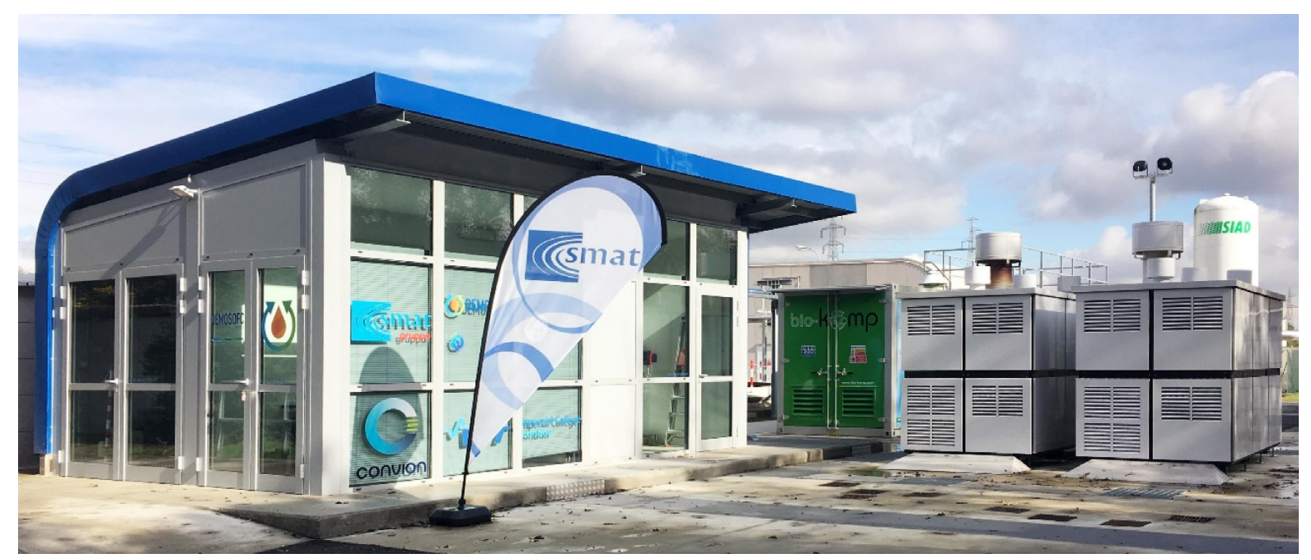

Fig. 12 - DEMOSOFC plant with 2 SOFC modules in operation (December 2018). On the left, the technical building where the control room and the electrical cabinet room are located. In the central part, the first SOFC module. On the right, part of the biogas cleaning and compression container.

- $c_{p, \mathrm{H}_{2} \mathrm{O}+\text { glycol }}$ has been evaluated as a weighted average value between the water specific heat and the glycol specific heat (given by the glycol supplier in the datasheet).

- $\left(T_{w, \text { out }}-T_{w, \text { in }}\right)$ is the difference between the outlet and inlet water temperature. Nominal set point for these values are $45^{\circ} \mathrm{C}$ inlet and $70^{\circ} \mathrm{C}$ outlet.

Biogas compression and de-humidification system, compressed air compressor, electrical cabinets conditioning, secondary heat recovery loop and similar extra-equipment with respect to the SOFC module are not included in the above-mentioned electrical efficiency. The reasons for not including them are:

- The plant is designed for 3 modules. With the current 1module operation this Balance of Plant (BoP) section is working in a non-optimal operating point thus affecting the net efficiency calculation.
- The information on the auxiliary consumption is measured as a total value of the whole equipment, even if some of them are working not only for the DEMOSOFC area. This is the case of the compressed air compressor, which is connected to the WWTP compressed air line but is feeding the DEMOSOFC system only during start-up operation. The compressor has been connected (in terms of power supply) to the DEMOSOFC plant in order to guarantee pressurized air (if needed) during island mode operation (see section 4.4).

\section{Heat recovery section}

Heat recovered from the SOFC units is completely transferred to the sludge entering the anaerobic digester through an intermediate water-glycol loop (30\% glycol in water). Circulation pumps (twin pumps to avoid stops during maintenance) and

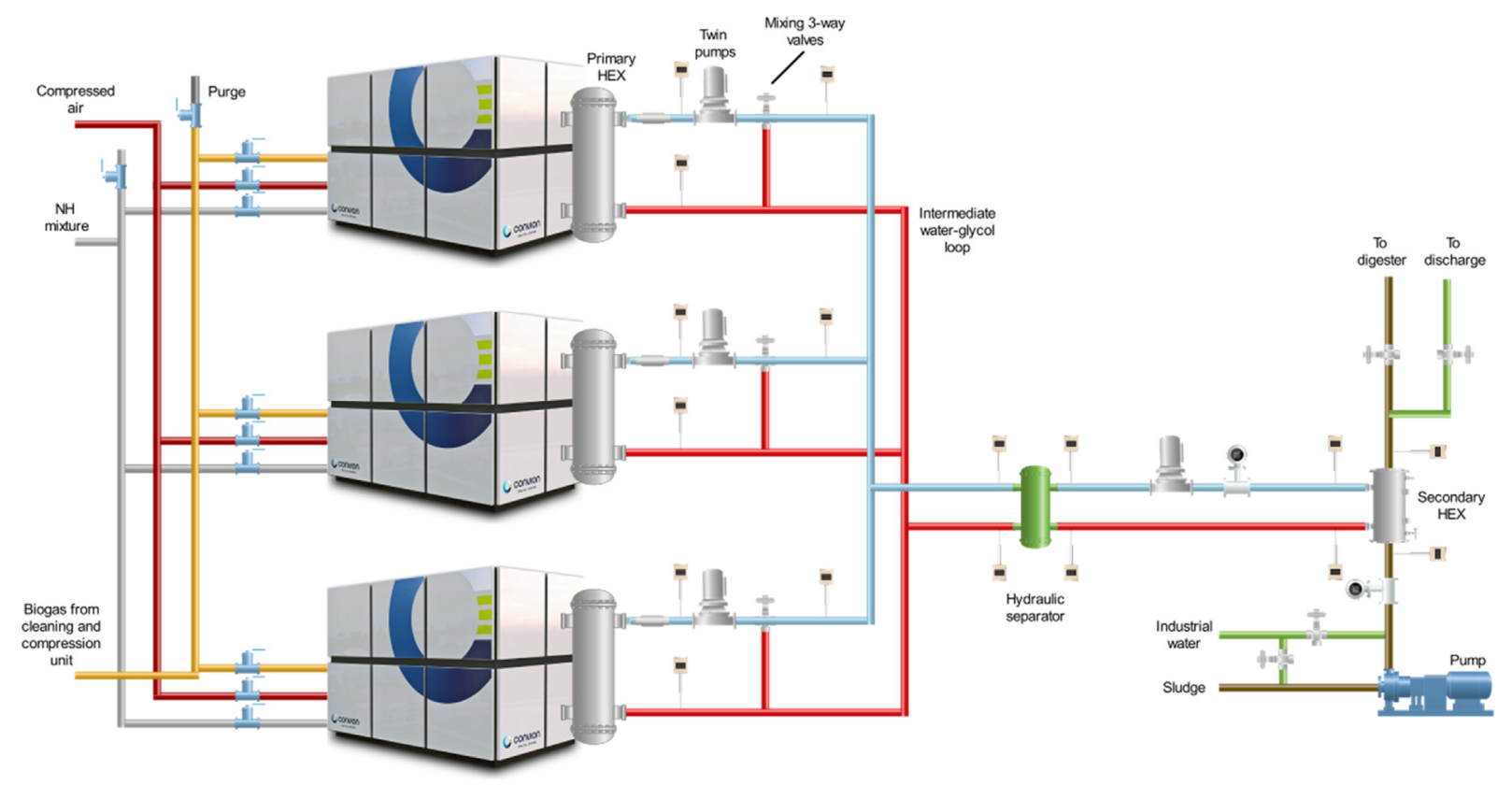

Fig. 13 - SOFC module and heat recovery section P\&ID. 
three-way valves for regulation have been installed (Fig. 13), and a new sludge-water heat exchanger is supporting the existing one.

The regulation of the DEMOSOFC system is performed by an automatic control system and is based on PID controllers. SOFC module setpoint is varied in accordance with the gas holder level, while water temperatures in the heat recovery section are controlled by varying the pumps speed and the mixing valves opening ratios.

\section{Electrical system}

Fig. 14 shows the electrical layout of the DEMOSOFC system. The SOFC module is designed to be installed parallel to power grid but is capable of island mode, thus securing critical power loads within a micro grid. The following phases [7] can be observed, by looking at Fig. 14:

- During the start-up of the system, auxiliaries (green line) are supplied by the dedicated line from the grid (green line), and the SOFC modules also take power from the grid for the heating phase (blue line);

- During nominal operation the SOFC modules are producing power to the grid (blue line, reverse flow respect to startup) and auxiliaries can either be fed from the grid (green line) or the SOFC modules (through the purple line);

- During island mode operation - i.e., the grid (grey line) is off either due to a grid failure or a grid disconnection by the grid protection device - both blue and green lines are no longer active. The SOFC will thus reduce its power output until the auxiliaries load requirement is reached, and will guarantee, through the purple and yellow lines, power supply to its auxiliaries. The SOFC could also secure additional loads that are critical for the overall site operation. Such critical loads could be connected to the threephase load line (red line), which is already available at the plant site. In the presented configuration, the presence of the UPS protects critical loads during the 'switch' time (0.5-1 s) required by the SOFC inverter to go into island mode. This switching time could be avoided by having the SOFC + battery + critical loads working always and continuously in a micro-grid mode

\section{Results}

The DEMOSOFC plant has started its operation, with the first module start-up, at the end of October 2017. The second module was started in October 2018. Planned maintenance activities during the operation period were devoted to optimizing the biogas feeding line and to install a mandatory power meter on the power production line. More than $5500 \mathrm{~h}$ of operation have been now collected and results are under analysis.

SOFC start-up procedure from the cold state to full load lasted around $48 \mathrm{~h}$. First tests were devoted to verifying the functionality of all internal equipment after the transport of the first C50 module to Italy and to set the regulation parameters. The cleaning system was previously tested from the early summer 2017 to verify the effectiveness of the contaminants removal and check measurements from the online gas analyzer.

Biogas raw composition is measured once per day by the online Qualvista analyzer (sample \#3 in Fig. 9). Clean biogas (both between and after the lead-and-lag reactors, respectively sample\#1 and sample \#2 in Fig. 9) is indeed measured

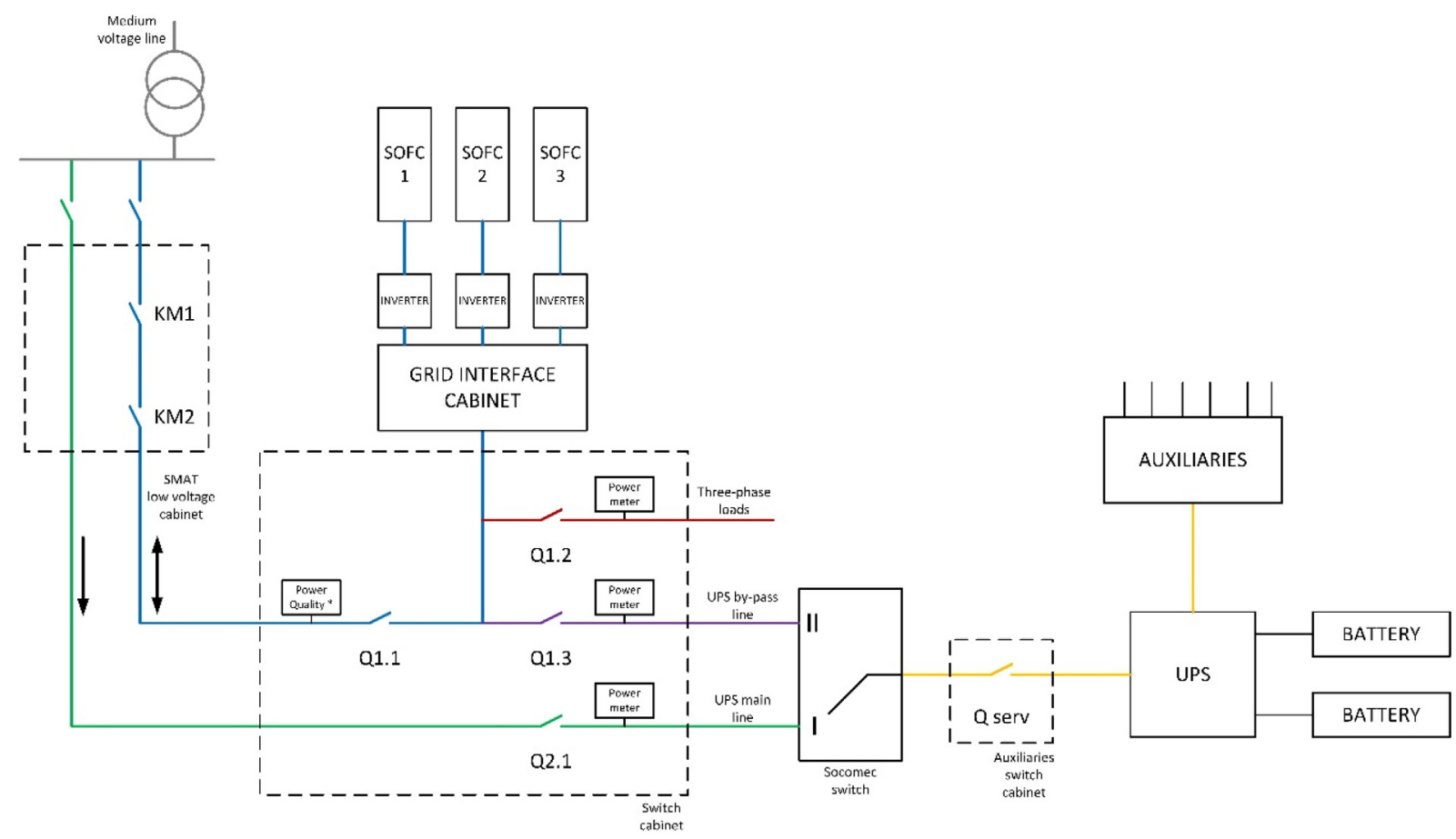

Fig. 14 - Electrical layout. 
continuously for the other hours of the day. Each measurement (performed in batch mode) takes $40 \mathrm{~min}$, and $\mathrm{N}_{2}$ is flushed after raw gas analysis.

Results on the raw biogas composition (in terms of contaminants) are shown in Fig. 15. As can be seen, $\mathrm{H}_{2} \mathrm{~S}$ content has been in line with historical trends with an average value of $33 \mathrm{ppm}$ ( $\min 1.8 \mathrm{ppm}-\max 71 \mathrm{ppm}$ ). Siloxanes are also varying in a limited range with an average value in the analyzed period of $4.1 \mathrm{mg} / \mathrm{m}^{3}\left(\min 0 \mathrm{mg} / \mathrm{m}^{3}-\max 9.4 \mathrm{mg} / \mathrm{m}^{3}\right)$. The concentration of $\mathrm{H}_{2} \mathrm{~S}$ has been found to be strongly linked with the iron oxide dosing in the water line (iron oxide is used to precipitate phosphor but also reduce the sulfur content in the water): the highest the dosing of iron oxide, the lower the $\mathrm{H}_{2} \mathrm{~S}$ in the outlet biogas. Siloxane variations are probably due to seasonal trends, already detected in the design phase: seasonal effect on silicon was in fact already registered in previous experiences in WWTP biogas analysis [32-34]. Average methane content in the same period (Fig. 16) has been $62 \%$ ( $\min 56 \%-\max 68 \%$ ). Methane content is stable on an hourly basis while weekly-monthly variations have been detected. Anyway, a minimum quantity around 55-56\% was always guaranteed: $\mathrm{CH}_{4}$ content value is transferred to the SOFC control system which is regulating the flow rate according to the methane.

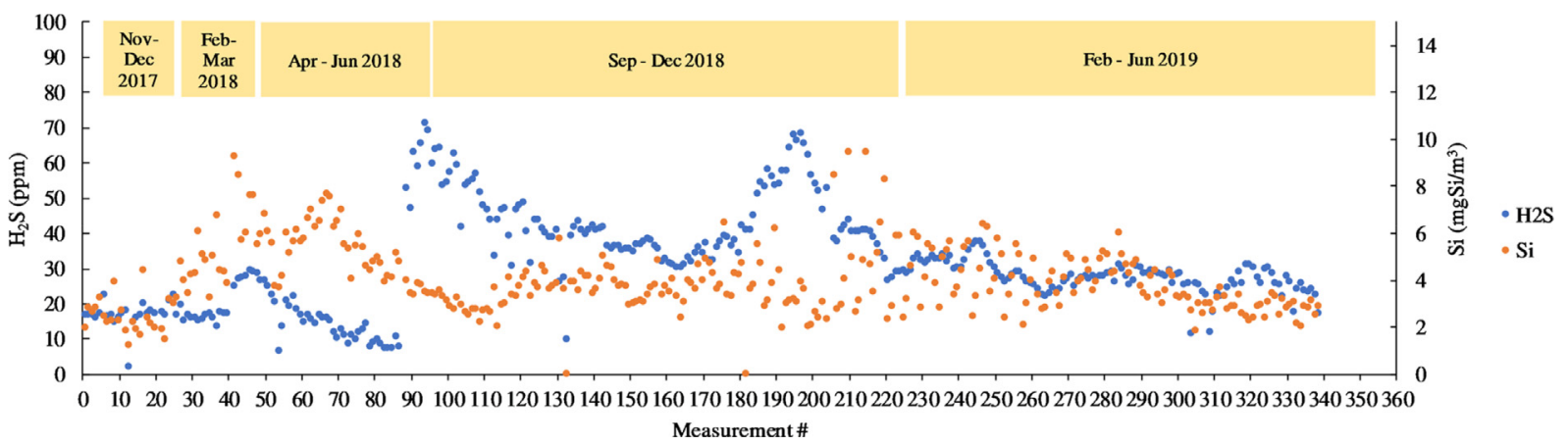

Fig. 15 - Raw biogas micro-composition $\left(\mathrm{H}_{2} \mathrm{~S}\right.$ and total silicon).

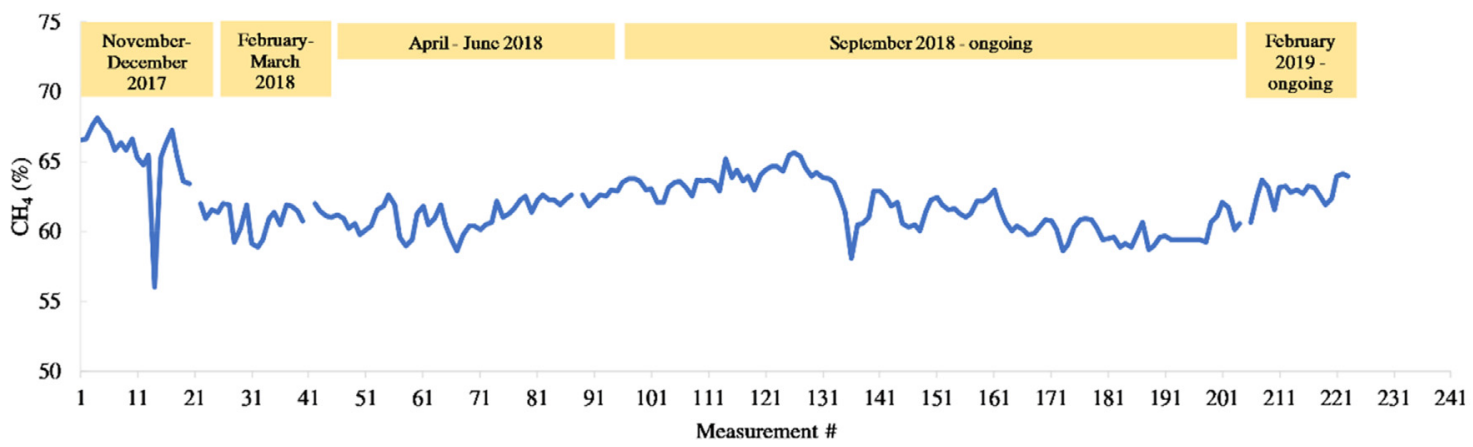

Fig. 16 - Raw biogas macro-composition $\left(\mathrm{CH}_{4}\right)$.

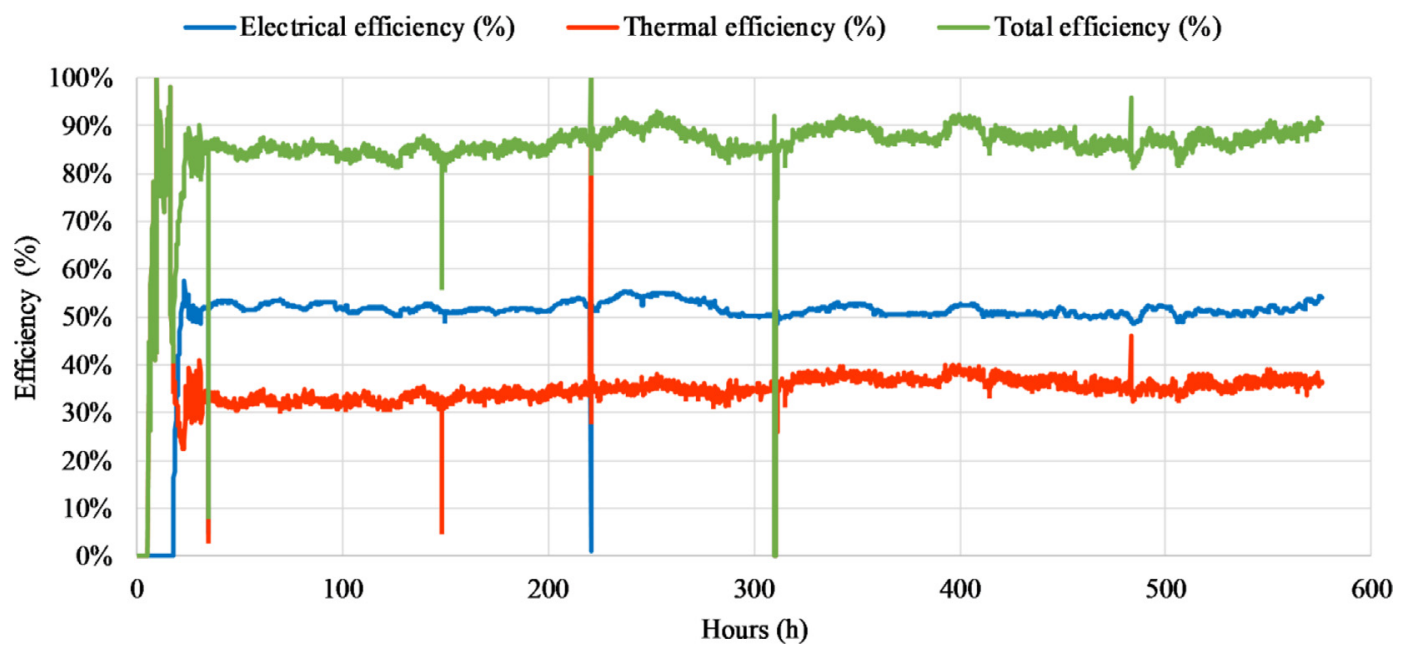

Fig. 17 - Efficiency plot for the 600-h operation period (from April 20th). 


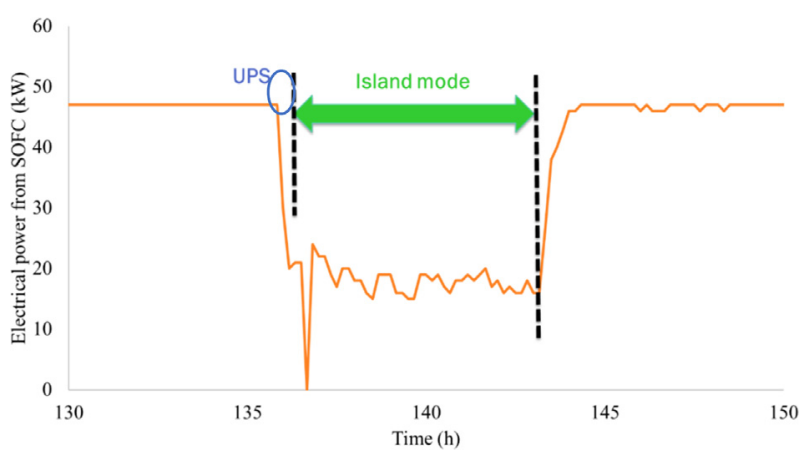

Fig. 18 - Island mode testing.

On the clean side of the analyzer ( $\mathrm{S} 1$ and $\mathrm{S} 2$ sampling ports), no breakthrough of contaminants has been detected so far (after $\sim 5600 \mathrm{~h}$ of operation). The $\mathrm{H}_{2} \mathrm{~S}$ and Total Silicon values have always been lower or comparable detection limit (from Table 4). An external laboratory has also been involved to verify the results from the online analyzer and results on the clean side have always been below the instrumentation (MS-GC) detection limit. Analysis on siloxanes were performed by the external laboratory both with Chemical Desorption (UNI CEN/TS 13649:2015 [35]) and Thermal Desorption method (UNI EN ISO 16017-1:2002 [36]). Results were comparable with both methods.

Considering an average biogas composition ( $31.16 \mathrm{ppm}$ $\mathrm{H}_{2} \mathrm{~S}$ and $3.98 \mathrm{mgSi} / \mathrm{m}^{3}$ ), an average biogas flow rate of $14 \mathrm{~m}^{3} / \mathrm{h}$ and a total number of operating hours (until June 2019) equal to $7700 \mathrm{~h}$, current (and minimum) loading rate for the sorbents have been determined. The calculation has been performed for the first 2 vessels, filled with $\sim 250 \mathrm{~kg}$ of sorbents each. Minimum loading rate is $1.83 \%$ for $\mathrm{CKC}\left(\mathrm{H}_{2} \mathrm{~S}\right.$ removal sorbent) and $0.17 \%$ for $\mathrm{C} 64$ (siloxanes removal sorbent). Because of the limited operation time and especially because of the reduced biogas flow rate respect to the cleaning unit design (1 out of 3 modules running) sorbents still show a high loading rate to be exploited.
Concerning the SOFC module operation and performance, Fig. 17 shows the results of $600 \mathrm{~h}$ of operation (from April to May 2018) according to the equations shown in Section SOFC modules. The SOFC module, controlled by the local operator panel, is set to $90 \%$ and is continuously producing $53 \mathrm{~kW}$. Electrical efficiency has always been stable and with values higher than $50 \%$ (range $50-53 \%$ at $53 \mathrm{~kW}_{\mathrm{e}}$ ). Net electrical efficiency of the whole plant (including also auxiliary equipment outside the SOFC module) can be estimated in a 5\% loss of the current biogas-to-AC power electrical efficiency: as explained above, the loss is relevant because the entire plant - designed for 3 SOFC modules - is currently operating in offdesign conditions with only one unit running. An efficiency peak of $56 \%$ has been reached at $40 \mathrm{~kW}_{\mathrm{e}}$ power output. No degradation effect is visible yet.

Thermal efficiency (in Fig. 17 showed at the water side of the heat exchanger installed inside the SOFC module) presents an average value of $31.4 \%$ (average total efficiency $82 \%$ ). Temperature losses between the SOFC module and the secondary sludge-water HEX are always lower than $3{ }^{\circ} \mathrm{C}$ on the hot side.

Fig. 18 shows the SOFC power output trend during a dedicated island mode testing at DEMOSOFC site (December 2017). As can be seen, after a first 'transition' phase (managed by the UPS), the SOFC can power the loads. Island mode was tested for a full working day. Re-connection to the grid was also tested, and power output went back to the set-point $\left(47 \mathrm{~kW}_{\mathrm{e}}\right.$ on that day). After this initial test, island mode was automatically managed by the control system in case of grid failures or blackouts.

VTT Technical Research Centre of Finland [37], partner of the DEMOSOFC project, has performed onsite emissions analysis at the DEMOSOFC plant on December 7th, 2017. Results are shown in Fig. 19. Gas emissions have been measured with Fourier Transform Infrared Spectroscopy (FTIR) (Gasmet Dx4000N). Particulate matters are measured with Electronic Low Pressure Impactor (ELPI). Results show that $\mathrm{NO}_{\mathrm{x}}, \mathrm{SO}_{2}, \mathrm{HCl}$, $\mathrm{HF}$, and organic compounds are all below detection limits. Particulate matter (on the right side of Fig. 19) shows that

\begin{tabular}{l|c|c}
\hline Species & Unit & Measured value \\
\hline $\mathrm{H}_{2} \mathrm{O}$ & Vol-\% & 4.7 \\
\hline $\mathrm{CO}_{2}$ & $\mathrm{Vol}-\%$ & 3.4 \\
\hline $\mathrm{CO}$ & $\mathrm{mg} / \mathrm{m}^{3}$ & $<9$ \\
\hline $\mathrm{CH}_{4}$ & $\mathrm{mg} / \mathrm{m}^{3}$ & $<2$ \\
\hline $\mathrm{N}_{2} \mathrm{O}$ & $\mathrm{mg} / \mathrm{m}^{3}$ & $<8$ \\
\hline $\mathrm{NO}$ & $\mathrm{mg} / \mathrm{m}^{3}$ & $<20$ \\
\hline $\mathrm{NO}_{\mathbf{x}}\left(\mathrm{as} \mathrm{NO}_{2}\right)$ & $\mathrm{mg} / \mathrm{m}^{3}$ & $<20$ \\
\hline $\mathrm{SO}_{2}$ & $\mathrm{mg} / \mathrm{m}^{3}$ & $<8$ \\
\hline $\mathrm{C}_{2} \mathrm{H}_{6}$ & $\mathrm{mg} / \mathrm{m}^{3}$ & $<14$ \\
\hline $\mathrm{HCHO}$ & $\mathrm{mg} / \mathrm{m}^{3}$ & $<7$ \\
\hline $\mathrm{HF}$ & $\mathrm{mg} / \mathrm{m}^{3}$ & $<10$ \\
\hline $\mathrm{HCl}$ & $\mathrm{mg} / \mathrm{m}^{3}$ & $<10$ \\
\hline $\mathrm{SO} \mathrm{F}_{2}$ & $\mathrm{mg} / \mathrm{m}^{3}$ & $<10$ \\
\hline $\mathrm{O}_{2}$ & $\mathrm{Vol}-\%$ & 18.3 \\
\hline Particulate & $\mathrm{mg} / \mathrm{m}^{3}$ & 0.01 \\
\hline
\end{tabular}

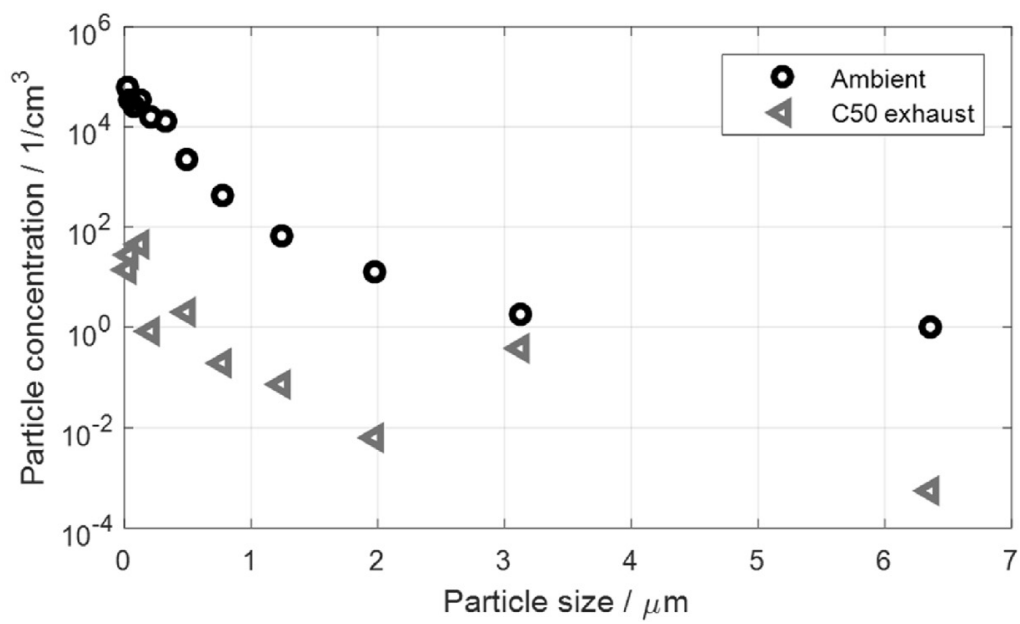

Fig. 19 - Results of the emissions analysis (performed on December 7th) at the DEMOSOFC site (courtesy of VTT [37]). 
Table 5 - Emissions analysis comparison with existing standards for biogas engines in EU and US area.

\begin{tabular}{|c|c|c|c|c|}
\hline & $\mathrm{NO}_{\mathrm{x}}$ & $\mathrm{CO}$ & Others & Ref. \\
\hline US & 150 ppm @ 15\% O & 610 ppm @ 15\% O & TOC - 80 ppm @ 15\% $\mathrm{O}_{2}$ & [38] \\
\hline Austria & $400-500 \mathrm{mg} / \mathrm{Nm}^{3}$ & $400-650 \mathrm{mg} / \mathrm{Nm}^{3}$ & $\begin{array}{l}\text { Non-methane hydrocarbons } \\
150 \mathrm{mg} / \mathrm{Nm}^{3}\end{array}$ & [39] \\
\hline Germany & $190-500 \mathrm{mg} / \mathrm{Nm}^{3}$ & $1000 \mathrm{mg} / \mathrm{Nm}^{3}$ & $\begin{array}{l}\mathrm{SO}_{2} \\
60-190 \text { (existing) } \mathrm{mg} / \mathrm{Nm}^{3} \\
40 \text { (new) } \mathrm{mg} / \mathrm{Nm}^{3}\end{array}$ & {$[39,40]$} \\
\hline Italy & $300 \mathrm{mg} / \mathrm{Nm}^{3}$ & $150 \mathrm{mg} / \mathrm{Nm}^{3}$ & $\begin{array}{l}\mathrm{TOC}-20 \mathrm{mg} / \mathrm{Nm}^{3} \\
\mathrm{SO}_{\mathrm{x}}-35 \mathrm{mg} / \mathrm{Nm}^{3}\end{array}$ & {$[39,41-43]$} \\
\hline Belgium & $190 \mathrm{mg} / \mathrm{Nm}^{3}$ & $500 \mathrm{mg} / \mathrm{Nm}^{3}$ & & [44] \\
\hline Netherlands & $340 \mathrm{mg} / \mathrm{Nm}^{3}$ & & $\mathrm{SO}_{2}-200 \mathrm{mg} / \mathrm{Nm}^{3}$ & [44] \\
\hline Switzerland & $250 \mathrm{mg} / \mathrm{Nm}^{3}$ & $650 \mathrm{mg} / \mathrm{Nm}^{3}$ & $\mathrm{PM}-10 \mathrm{mg} / \mathrm{Nm}^{3}$ & [44] \\
\hline DEMOSOFC plant & $<20 \mathrm{mg} / \mathrm{m}^{3}$ & $<9 \mathrm{mg} / \mathrm{m}^{3}$ & $\mathrm{SO}_{2}<8 \mathrm{mg} / \mathrm{m}^{3}$ & [45] \\
\hline
\end{tabular}

particulate concentration in the surrounding ambient air is higher than the one in the SOFC module exhaust gases: the system is indeed filtering ambient inlet air. These numbers underline the real 'zero-emission' concept within the fuel cellbased installations. The results have been also compared with existing limits in US and EU area for biogas engines (Table 5): SOFC emissions are strongly below all the currently available limits and will be compliant with possible future reduction of the current values.

\section{Conclusions}

The DEMOSOFC plant is running since October 2017, with some intermediate stops for maintenance activities.

The plant (3 SOFC modules, $174 \mathrm{~kW}_{\mathrm{e}}$ electric of nominal capacity) has been sized to optimize its energy integration within the WWTP, which shows a variable biogas production profile and a high electrical and thermal request. An Energy Planner Tool software has been developed to optimize the system size: the goal was to maximize the use of biogas in the cogeneration system and the capacity factor of the SOFC modules. The best options were between three and four modules, but the 3-modules size was preferred because it was related to a lower number of shutdown per year (due to biogas fluctuations), and thus to lower stress for the fuel cell system.

Within the plant operation - besides the planned stop phases - the SOFC modules have always worked under a stable operation point (usually $90-100 \%$ of the full power) producing electrical and thermal energy for the WWTP. Efficiency has always been higher than $48-50 \%$ (from compressed biogas to AC power) with a peak of $56 \%$. The consumption of the compressor machine only is on average $1.9 \mathrm{~kW}_{\mathrm{e}}$. Other auxiliaries' consumption is under evaluation since the number, and the type of components strongly depends on the design of the entire system: already existing chillers in the plant, location of the system respect to the biogas production area, heat recovery system layout, etc.

Future works will be focused on the long-term operation of the part. Degradation analysis and stack substitution will be analyzed, together with current (and optimized) plant preparation costs. The goal of the overall activity is to prove - with a real long-term onsite testing - the advantages of the SOFC systems coupled with biogas feeding and to associate these technical results with a reliable and optimized plant cost.

\section{Acknowledgments}

This project has received funding from the Fuel Cells and Hydrogen 2 Joint Undertaking under grant agreement No 671470. This Joint Undertaking receives support from the European Union's Horizon 2020 research and innovation programme, Hydrogen Europe and Hydrogen Europe research.

The authors wish to thanks Angelo Le Pera for his support in the development of the EPT.

\section{R E F E R E N C E S}

[1] Gandiglio M, Lanzini A, Soto A, Leone P, Santarelli M. Enhancing the energy efficiency of wastewater treatment plants through co-digestion and fuel cell systems. Front Environ Sci 2017;5:70. https://doi.org/10.3389/ FENVS.2017.00070.

[2] European Environment Agency. Urban waste water treatment maps. http://www.eea.europa.eu/data-and-maps/ uwwtd/interactive-maps/urban-waste-water-treatmentmaps-1. [Accessed 12 January 2017].

[3] Sechi S, Giarola S, Lanzini A, Gandiglio M, Oluleye G, Santarelli M, et al. Techno-economic assessment of the effects of biogas rate fluctuations on industrial applications of solid-oxide fuel cells. Comput Aided Chem Eng 2017;40:1-6. https://doi.org/10.1016/B978-0-444-639653.50151-3.

[4] Convion Fuel Cell Systems. Convion official website. 2017. http://convion.fi/. [Accessed 11 April 2019].

[5] ASUE Arbeitsgemeinschaft für sparsamen und umweltfreundlichen Energieverbrauch e.V. BHKWKenndaten 2014/15. ASUE; 2015.

[6] Rillo E, Gandiglio M, Lanzini A, Bobba S, Santarelli M, Blengini G. Life cycle assessment (LCA) of biogas-fed solid oxide fuel cell (SOFC) plant. Energy 2017;126:585-602. https:// doi.org/10.1016/j.energy.2017.03.041.

[7] Gandiglio M, Lanzini A, Santarelli M. Large stationary Solid oxide fuel cell (SOFC) power plants. Cham: Springer; 2018. p. 233-61. https://doi.org/10.1007/978-3-319-75602-8_8.

[8] DEMOSOFC project official website. 2016. www.demosofc.eu. [Accessed 20 December 2015].

[9] Margalef P, Brown T, Brouwer J, Samuelsen S. Conceptual design and configuration performance analyses of polygenerating high temperature fuel cells. Int J Hydrogen Energy 2011;36:10044-56. https://doi.org/10.1016/ j.ijhydene.2011.05.072.

[10] Fuel Cell Energy. Fuel cell power plants: biofuel case study Tulare. CA: DOE-NREL Workshop; 2012. 
[11] Gandiglio M, Drago D, Santarelli M. Techno-economic analysis of a solid oxide fuel cell installation in a biogas plant fed by agricultural residues and comparison with alternative biogas exploitation paths. Energy Procedia 2016;101:1002-9. https://doi.org/10.1016/j.egypro.2016.11.127.

[12] Santarelli M, Briesemeister L, Gandiglio M, Herrmann S, Kuczynski P, Kupecki J, et al. Carbon recovery and reutilization (CRR) from the exhaust of a solid oxide fuel cell (SOFC): analysis through a proof-of-concept. J CO2 Util 2017;18:206-21. https://doi.org/10.1016/j.jcou.2017.01.014.

[13] Sorace M, Gandiglio M, Santarelli M. Modeling and techno-economic analysis of the integration of a FCbased micro-CHP system for residential application with a heat pump. Energy 2016. https://doi.org/10.1016/ j.energy.2016.11.082.

[14] Argonne National Laboratory, U.S. Department of energy, fuel cell technologies office. In: Gas Clean-Up for Fuel Cell Applications Workshop - March 6-7, 2014; 2014. https:// www.energy.gov/sites/prod/files/2016/04/f30/ fcto_gas_cleanup_workshop_report.pdf.

[15] Saadabadi SA, Thallam Thattai A, Fan L, Lindeboom REF, Spanjers H, Aravind PV. Solid oxide fuel cells fuelled with biogas: potential and constraints. Renew Energy 2019;134:194-214. https://doi.org/10.1016/ j.renene.2018.11.028.

[16] Biocell project. BIOCELL - energy self-sustaining and environmental footprint reduction on wastewater treatment plants via fuel cells n.d. http://ec.europa.eu/environment/ life/project/Projects/index.cfm?fuseaction=search. dspPage\&n_proj_id=3279. [Accessed 23 July 2019].

[17] SOFCOM project. Final report summary - SOFCOM (SOFC CCHP with POLY-FUEL: OPERATION and maintenance). 2015. https://cordis.europa.eu/project/rcn/101098/reporting/en.

[18] Santarelli M, Lanzini A, Gandiglio M, Le Pera A, Lorenzi E, Hakala T, et al. Energy planning of the DEMOSOFC (Deliverable of the DEMOSOFC EU project). 2015. http://www. demosofc.eu/?attachment_id=862. [Accessed 12 April 2019].

[19] MosayebNezhad M, Mehr AS, Gandiglio M, Lanzini A, Santarelli M. Techno-economic assessment of biogas-fed CHP hybrid systems in a real wastewater treatment plant. Appl Therm Eng 2018;129:1263-80. https://doi.org/10.1016/ J.APPLTHERMALENG.2017.10.115.

[20] Mehr AS, Gandiglio M, MosayebNezhad M, Lanzini A, Mahmoudi SMS, Yari M, et al. Solar-assisted integrated biogas solid oxide fuel cell (SOFC) installation in wastewater treatment plant: energy and economic analysis. Appl Energy 2017;191:620-38. https://doi.org/10.1016/ J.APENERGY.2017.01.070.

[21] Giarola S, Forte O, Lanzini A, Gandiglio M, Santarelli M, Hawkes A. Techno-economic assessment of biogas-fed solid oxide fuel cell combined heat and power system at industrial scale. Appl Energy 2018;211:689-704. https://doi.org/10.1016/ J.APENERGY.2017.11.029.

[22] Sumbera J. Modelling generator constraints for the selfscheduling problem. Ved Semin Doktorandu FIS-Únor 2012:1-12.

[23] Papurello D, Silvestri S, Lanzini A. Biogas cleaning: trace compounds removal with model validation. Separ Purif Technol 2019;210:80-92. https://doi.org/10.1016/ j.seppur.2018.07.081.

[24] Coppola G, Papurello D. Biogas cleaning: activated carbon regeneration for $\mathrm{H} 2 \mathrm{~S}$ removal. Cleanroom Technol 2018;1:40-57. https://doi.org/10.3390/cleantechnol1010004.

[25] Papurello D, Santarelli M, Fiorilli S. Physical activation of waste-derived materials for biogas cleaning. Energies 2018;11:2338. https://doi.org/10.3390/en11092338.
[26] Drago D. The sulfur issue in fuel cell based cogenerative systems. Politecnico di Torino; 2017.

[27] Sitthikhankaew R, Chadwick D, Assabumrungrat S, Laosiripojana N. Effects of humidity, O2, and $\mathrm{CO} 2$ on $\mathrm{H} 2 \mathrm{~S}$ adsorption onto upgraded and $\mathrm{KOH}$ impregnated activated carbons. Fuel Process Technol 2014;124. https://doi.org/ 10.1016/j.fuproc.2014.03.010.

[28] Barelli L, Bidini G, de Arespacochaga N, Pérez L, Sisani E. Biogas use in high temperature fuel cells: enhancement of $\mathrm{KOH}-\mathrm{KI}$ activated carbon performance toward H2S removal. Int J Hydrogen Energy 2017;42:10341-53. https://doi.org/ 10.1016/J.IJHYDENE.2017.02.021.

[29] Isik-Gulsac I, Isik-Gulsac I. Investigation of impregnated activated carbon properties used in hydrogen sulfide fine removal. Braz J Chem Eng 2016;33:1021-30. https://doi.org/ 10.1590/0104-6632.20160334s20150164.

[30] Qualvista Ltd - official website n.d. http://www.qualvista. $\mathrm{com} /$ (accessed January 8, 2018).

[31] Home Page | Bio-komp.com - official website n.d.. http:// www.bio-komp.com/index.php. [Accessed 8 January 2018].

[32] Gandiglio M, Lanzini A, Santarelli M, Leone P. Design and balance of plant of a demonstration plant with a Solid Oxide Fuel Cell fed by biogas from Waste-water and exhaust carbon recycling for algae growth. J Fuel Cell Sci Technol 2013;11:14. https://doi.org/10.1115/FuelCell201318082.

[33] Lanzini A, Madi H, Chiodo V, Papurello D, Maisano S, Santarelli M, et al. Dealing with fuel contaminants in biogasfed solid oxide fuel cell (SOFC) and molten carbonate fuel cell (MCFC) plants: degradation of catalytic and electro-catalytic active surfaces and related gas purification methods. Prog Energy Combust Sci 2017;61:150-88. https://doi.org/10.1016/ j.pecs.2017.04.002.

[34] Papadias DD, Ahmed S, Kumar R. Fuel quality issues with biogas energy - an economic analysis for a stationary fuel cell system. Energy 2012;44:257-77. https://doi.org/10.1016/ j.energy.2012.06.031.

[35] UNI Standard. UNI CEN/TS 13649:2015 - stationary source emissions - determination of the mass concentration of individual gaseous organic compounds - sorptive sampling method followed by solvent extraction or thermal desorption. 2015.

[36] UNI Standard. UNI EN ISO 16017-1:2002 - indoor, ambient and workplace air - sampling and analysis of volatile organic compounds by sorbent tube/thermal desorption/capillary gas chromatography - pumped sampling. 2002.

[37] VTT | VTT technical research Centre of Finland Ltd technology for business n.d. https://www.vttresearch.com/ (accessed May 15, 2018).

[38] Environmental Protection Agency (EPA). Standards of performance for stationary spark ignition internal combustion engines and national emission standards for hazardous air pollutants for reciprocating internal combustion E. 2008.

[39] Benato A, Macor A, Rossetti A. Biogas engine emissions: standards and on-site measurements. Energy Procedia 2017;126:398-405. https://doi.org/10.1016/ j.egypro.2017.08.278.

[40] Emission Standards. Germany: stationary engines: TA luft n.d. https://www.dieselnet.com/standards/de/taluft.php. [Accessed 25 July 2019].

[41] Gazzetta Ufficiale Della Repubblica Italiana. Anno $157^{\circ}$ Numero 151. 2016.

[42] Tiberio M. Le principali modifiche di alcuni valori di emissione e degli allegati alla parte Quinta del D.Lgs. 152/06 e s.m.i. Ordine Reg. dei Chim. del Friuli-Venezia Giulia; 2018. 
[43] Gazzetta Ufficiale - Decreto Legislativo 3 aprile 2006, n. 152. 2006. n.d, https://www.gazzettaufficiale.it/atto/serie_ generale/caricaDettaglioAtto/originario?atto. dataPubblicazioneGazzetta=2006-04-14\&atto. codiceRedazionale=006G0171. [Accessed 24 July 2019].
[44] VDMA (Verband Deutscher Maschinen- und Anlagenbau). Exhaust emission legislation: diesel-and gas engines. [n.d].

[45] Rautanen M, Vesala H, Kajolinna T, Pellikka T. DEMOSOFC project - deliverable number 4.3-a Analysis of the emissions from the DEMO. 2018. 